International Journal of Linguistics, Literature and Translation

ISSN: 2617-0299 (Online); ISSN: 2708-0099 (Print)

DOI: $10.32996 / \mathrm{ijllt}$

Journal Homepage: www.al-kindipublisher.com/index.php/ijltt

\title{
Feminism and Gynecocracy in Classical Autors Dona María de Zayas Sotomayor and Tirso de Molina
}

\author{
Cossi Basile Medenou 8 (D) \\ Université d'Abomey-Calavi Départment de Philologie Hispanique et des civilisations Afro-américaines \\ $\triangle$ Corresponding Author: Cossi Basile Medenou, E-mail: medenoubasile@gmail.com
}

ARTICLE INFORMATION
Received: June 13, 2021
Accepted: July 19, 2021
Volume: 4
Issue: 7
DOI: $10.32996 /$ ijllt.2021.4.7.20
KEYWORDS

Objectification, feminism, femininity, empowerment, gynecocracy.

\section{ABSTRACT}

This study based on María de Zayas Sotomayor and_Tirso de Molina, especially on their classical Golden Age books Prudence in Woman and Amorous and Exemplary Novels, has for purposes to raise the question of women empowerment again and analyze their handling approaches of the feminist subject matter, to identify and suggest solutions to the hindrances of the solvency of that social phenomenon of women discrimination now a days. We carried it out by socio-critical approach and with objective, comparative, esthetical and analytic heuristic methods. It turns out of our work that both of María de Zayas Sotomayor and_Tirso de Molina are feminist writers, but there are some subtle differences between them: Tirso de Molina put special emphasis on women political skills, whereas María de Zayas develops femininity, condemns their objectification by men and advocates their intellectual and social emancipation. Apart from that, our analyzes revealed that social and cultural obstacles continue to maintain the phenomenon. We proposed a cleaning up of the habits and the lifting of old fashioned taboo, mainly in African cultural areas where such habits are still unchanging.

\begin{abstract}
Resumen
Iniciamos este estudio sobre María de Zayas Sotomayor y Tirso de Molina, más precisamente sobre sus obras Novelas amorosas y ejemplares y La prudencia en la mujer, con motivos de replantear la cuestión de empoderamiento de la mujer y analizar los enfoques de tratamiento de ese temario feminista por los dos autores clásicos, para identificar y hacer propuestas de soluciones a los estorbos a la solvencia del fenómeno social de discriminación de la gente femenina en la actualidad. Lo realizamos por un acercamiento socio crítico y por los métodos objetivo, comparativo, estético y analítico. Eso nos posibilita los resultados según los cuales María de Zayas Sotomayor y Tirso de Molina son todos feministas, con matices que Tirso hace hincapié en las destrezas políticas de la mujer, mientras que María de Zayas desarrolla la feminidad, denuncia su cosificación por los varones y predica su emancipación intelectual y social. Además, nuestros análisis nos revelan que pesadeces socio culturales siguen manteniendo el fenómeno. Por lo que hacemos propuestas de saneamiento de las costumbres y de levantamiento de algunos tabúes anticuados, sobre todo, en las áreas culturales africanas en las que tales hábitos parecen inmutables.

Palabras clave: cosificación, feminismo, feminidad, empoderamiento, ginecocracia.
\end{abstract}

\section{Introduction}

La literatura clásica del Siglo de Oro constituye una fuente inagotable de temáticas socio culturales y políticas. A título de ejemplos, la discriminación sexual y su solución el empoderamiento de la mujer, que siguen constituyendo planteamientos y problemáticas

\section{K C AL-KINDI CENTER \\ $\mathbf{R}$ DFOR RESEARCH AND}

Your gateway to world-class research

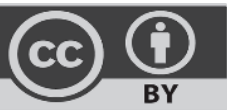

Published by Al-Kindi Center for Research and Development, London, United Kingdom. Copyright (c) the author(s). This open access article is distributed under a Creative Commons Attribution (CC-BY) 4.0 license 
de muchas tribunas y de muchos foros de ejecutivos de la mayor parte de los países, se debatían ya en muchas obras áureas y algunos autores se ilustraron en tales temarios. Elegimos en nuestro estudio éste a María de Zayas Sotomayor y a Tirso de Molina en sus obras Novelas amorosas y ejemplares y La prudencia en la mujer replantear la cuestión de empoderamiento de la mujer y analizar los enfoques de tratamiento de ese temario feminista por los dos autores clásicos, para identificar y hacer propuestas de soluciones a los obstáculos a la solvencia del fenómeno social de discriminación de la gente femenina en la actualidad. Lo articulamos en cinco puntos esenciales: el marco teórico del estudio; la presentación de los autores y sus obras; el estudio comparativo de las manifestaciones del feminismo y de la ginecocracia en las dos obras; la contextualización y actualización de la problemática; los estorbos a la emancipación de la mujer y enfoques de solución.

\section{Marco teórico del estudio \\ 2.1 Aclaración léxica \\ Feminidad}

La Feminidad o femineidad es el conjunto de cualidades que se manifiestan en mayor medida en las mujeres en una cultura particular. Es un concepto que alude a los valores, características y comportamientos tanto aprendidos, como a características específicamente biológicas. Su complemento es el concepto de masculinidad. El concepto de feminidad también se ha desarrollado como "ideal de feminidad" en el sentido de un patrón o modelo deseable de mujer.

Se entiende por feminidad un conjunto de atributos asociados al rol tradicional de la categoría mujer. Algunos ejemplos de esos atributos son la comprensión, la debilidad y vulnerabilidad, la muestra de afecto, la educación y los cuidados de la descendencia, etc. De manera que a lo largo de la historia de (al menos) los países occidentales, y todavía hoy día, las mujeres han sufrido una gran presión social para responder delante de las demás con comportamientos asociados a esos atributos.

De la misma manera, los atributos de la masculinidad deben ser asociados sólo a las del hombre, y, por tanto, nunca hasta hoy día, en que empieza a haber cierta permisividad y apertura de miras, ha sido bien considerado que una mujer tuviera actitudes asociadas con la masculinidad.

Lo cierto es que tanto los hombres como las mujeres, suelen tener actitudes diversas que no tienen por qué encajar dentro del binomio feminidad y masculinidad. De esta manera, por presión y reiteración de actitudes y roles, el binomio ha contribuido a generar desigualdades de género y discriminaciones a las mujeres.

La cultura de la feminidad depende completamente del contexto social, sobresaliendo el ideal de feminidad según la cultura de los países occidentales que complementan dichos ideales con los cánones de la belleza humana y los designios de la moda. La feminidad al igual que la masculinidad, son fundamentales en la construcción del concepto social de la belleza y la atracción sexual. Lo que en una sociedad y contexto histórico se considera como femenino, podría no considerarse como tal en otra sociedad o contexto histórico.

\section{Gineconomía}

Antiguamente (en la Antigua Grecia), la ginecomía era el sistema de gestión de los comportamientos de las mujeres en la sociedad. Así, los ginecónomos eran oficiales que tenían a cargo velar por el recato, los comportamientos sociales de las mujeres, y castigarlas conforme con el código de la vida de las mujeres en la sociedad. Hoy día, ese concepto ha cambiado de sentido y se entiende por la participación de la gente femenina en la vida económica: el estudio de los factores de éxito de las mujeres en la cabeza de las empresas económicas.

\section{Cosificación}

Es «considération de algo como cosa»_(González Maldonado C. y Hernández H., 2011:553). Según Cerdà Massó R., es " transformación de conceptos, teorías, hipótesis, etc, en objetos concretos, en realidades» (1986: 71). Pues, cosificar a una persona es considerarla como una cosa, o convertirla en una cosa. Y la persona de que se trata aquí en nuestro trabajo, es la mujer.

Se la cosifica, cuando se la utiliza para saciar sus apetitos sexuales, en vez de hacer el amor con ella, o se la considera elemento del decorado de un acontecimiento, en vez de actriz de dicho evento, o paritorio o receptáculo de producción de niños, en vez de pariente o partidario en un hogar familiar.

\section{Feminismo}

El feminismo es la «doctrina o movimiento social que defiende a la mujer y la reconoce capacidades y derechos antes sólo reservados a los hombres: el feminismo no defiende la superioridad de la mujer frente al hombre, sino su igualdad» (González, M., 
Hernández, H., 2011: 896). Según el diccionario francés Dictionnaire Universel, es la «doctrina, la actitud favorable a la defensa de los intereses propios a las mujeres y a la extensión de sus derechos» (Cerquiglini, B., Ollé, J-M. y al., 2008: 493).

Nosotros llamamos pre feminismo la defensa de la feminidad, los derechos y atributos de la mujer, defensa en forma de compromiso literario u organización social que se verificaron en épocas remotas, tal como el Siglo de Oro. Al respecto, elegimos presentar nuestro trabajo basándonos esencialmente en la escritora española María de Zayas y Sotomayor, la única que pudimos encontrar durante nuestras investigaciones sobre el feminismo en el Siglo de Oro.

En la actualidad, el feminismo propiamente hablando se defiende a través de ideologías y eslóganes internacionales pro feminista tales como el empoderamiento de la mujer, el género, igualdad entre hombres y mujeres, la discriminación positiva, etc.

El empoderamiento de la mujer enfoca el derecho y la obligación de conceder poderes, autoridades, cargos políticos y capacidades económicas a las mujeres a todos los niveles de la vida social, económica y política de cada país.

El género lucha para que en todos los proyectos de desarrollo, se tome en cuenta los intereses de las mujeres.

La igualdad entre hombres y mujeres significa que, en el campo de los derechos, la mujer debe tener los mismos derechos que el hombre.

La discriminación positiva especula que, en el goce de derechos laborales y cargos políticos, se conceda la prioridad a la mujer en detrimento del hombre.

\section{Empoderamiento}

El empoderamiento es « la adquisición de poder, la emancipación o la autonomía por parte de un grupo desfavorecido ». (González M. C. y Hernández H., 2011:753).

Entendemos por empoderamiento el nuevo concepto socio económico y político desarrollado en los países subdesarrollados y en los en vías de desarrollo, como alternativa para sacar adelante a los pueblos llamados del tercer mundo. En inglés se habla de "empowerment" ("women empower") y en francés "approche genre" o "empower" o "autonomisation".

Es un concepto que se fundamenta en la realidad socio económica según la cual las mujeres desempeñan importantes papeles en la vida de esos pueblos. A partir de esta realidad, la corriente ideológica enfoca conceder poderes socio económicos y políticos a las mujeres para que ellas contribuyan más que antes en el desarrollo de sus pueblos.

\section{Ginecocracia}

La ginecocracia es literalmente el poder de la mujer, en paralelo con la falocracia, el poder de los varones. Así entendida, la ginecocracia puede compararse al empoderamiento de la mujer. Pero, Gonzalez M. C. y Hernandez H. van más allá de este sentido, definiendo ese concepto como «supremacía de la mujer sobre el hombre» (2011: 971).

En este estudio, entendemos la ginecocracia como un empoderamiento, en términos de autonomización y de plenitud de derechos sociopolíticos, igual que el hombre, y tanto cuanto que se lo posibilite su feminidad. No predicamos cualquier supremacía de la gente femenina sobre los varones.

\section{Problemática, objetivos y metodología \\ 3.1 Problemática}

Las sociedades son varoniles o machistas en su mayoría, hasta actualidad, a pesar de que, muchas mujeres sobresalen en talentos y en el buen gobierno. Prueba de ello, los intensos aplausos de admiración durante seis minutos por parte del pueblo alemán, para la canciller alemana Angela Merckel, cuando ella se despedía de él y salía de su oficina para su jubilación. Hasta los equipamientos de trabajo están fabricados con estándares masculinos. Prueba de ello, mi computador rechaza la forma femenina del grupo de palabras " la canciller alemana " y me propone la forma masculina "el canciller alemán". Tal observación se hace a nivel de muchos conceptos. Las academias vienen ajustándose con la nueva tendencia de feminización de algunos conceptos. A pesar de eso, mucho queda por hacer, sobre todo en el campo laboral y sobre todo, en el desempeño de algunos cargos sociopolíticos, religiosos y económicos. Así que la cuestión núcleo de la problemática de nuestro estudio es la pertinencia o no del empoderamiento de la mujer y de la ginecocracia. Este planteamiento fundamental se fragmenta en otros conexos que son: ¿se equivocaría la Humanidad empoderando a la gente femenina? ¿no dan hoy las mujeres suficientes muestras de competencia y de buen gobierno para que las sociedades machistas se convenzan de que son oportunos el empoderamiento de la mujer y la 
ginecocracia? ¿Cuáles son los factores que disponen a la gente femenina a la jefatura? ¿Cuáles son los estorbos que siguen imposibilitando el empoderamiento y la ginecocracia?

\subsection{Objetivos del estudio}

El objetivo general de este estudio es didáctico y enfoca sensibilizar a los pueblos (los africanos en particular) a la necesidad urgente para la Humanidad de restablecer una justicia natural para aprovechar los tantos dones y las tantas competencias de la gente femenina.

De modo específico, nuestro trabajo enfoca mostrar que el combate feminista de empoderamiento queda vigente, ya que la discriminación sexual en contra de la mujer sigue corriendo vigencia; demostrar la pertinencia de esta lucha feminista para los intereses de desarrollo sostenible para las comunidades; llamar la atención sobre los dones femeninos y los ejemplos de buen gobierno por parte de las mujeres; identificar los obstáculos al pleno goce de todas las capacidades de la gente femenina por parte de los pueblos; hacer sugerencias y proponer mecanismos de su implementación para levantar esos obstáculos.

\subsection{Metodología}

\section{La investigación documental}

El corpus de nuestra investigación documental consta de dos obras fundamentales: Novelas amorosas y ejemplares de María de Zayas Sotomayor, y La prudencia en la mujer de Tirso de Molina. Además de esas obras de primera mano, consultamos muchas obras críticas y otros tantos documentos de erudición.

\section{El método objetivo}

El método objetivo «consiste en describir de manera imparcial y metódica una realidad o un fenómeno, independientemente de los intereses, gustos y prejuicios de la persona que hace la descripción» (Boutillier S., Goguel d'Allondais A. y al., 2005:163).

En el método objetivo, es preciso considerar el objeto de estudio como una realidad, fuera del espíritu de modo autónomo e independiente. El método objetivo obliga a objetivar el tema de estudio, es decir transformarlo en realidad objetiva que se puede someter a un estudio científico. Eso requiere establecer una distancia crítica y un protocolo de análisis preciso para evitar posiblemente la intervención de la subjetividad del investigador. El objetivo general de este método es atenerse a los datos controlables y apartar del campo de estudio los elementos subjetivos que no se pueden averiguar, para proponer una representación conforme con la realidad y un análisis rigoroso. El fundamento del método objetivo es la separación estricta del sujeto que lleva la investigación, del objeto de estudio.

Elegimos este método para recoger objetivamente los datos documentales, cotejarlos con nuestras propias experiencias sociales, antes de someter los datos recogidos al análisis.

\section{La estética}

La estética es la rama de la filosofía que trata de la belleza y de la teoría fundamental y filosófica del arte (M. González, H. Hernández y al., 2006: 845). Debido a que nuestro estudio se ubica en un marco literario, el método estético nos facilitará la función poética retórica de la obra: invención, disposición y elocución, $\ldots$

\section{El método comparativo}

Los criterios de comparación son la similitud, la equivalencia y la oposición. Esos diferentes criterios se utilizan en diversos niveles. Los utilizamos para comparar las cosechas documentales con los datos de nuestras propias experiencias sociales, antes de analizarlas de manera crítica.

\section{La sociocrítica}

En Literatura, la socio crítica es el «método de lectura crítica que pone el acento sobre la dimensión social del texto literario, analizando sobre todo de qué manera participa en la elaboración, la difusión y la evolución de las representaciones» (Merlet Ph., Berès A. y al. 2003: 946). La socio crítica es un acercamiento al hecho literario para estudiar la "socialidad" del texto, según las propias palabras de Claude Duchet quien inventó el término en 1971. Pues, la socio crítica es el estudio de las manifestaciones de lo social en la estructura de una obra o en un texto literario.

Optamos por la socio crítica aquí en este estudio, para analizar en un ángulo crítico los textos de nuestro corpus. Así que este método corre pareja con el método analítico.

\section{El método analítico}

El análisis es inductivo, deductivo y sintético. Se lo utiliza para aprovechar la revisión documental con la interpretación de los datos que nos permiten convalidar la factibilidad y la necesidad de la aplicación de nuestros resultados y nuestras propuestas de 
soluciones. Además, nuestro análisis será también dialéctico. La dialéctica de nuestros análisis consistirá en un procedimiento intelectual que considera siempre un fenómeno junto con su contrario, para inferir una síntesis. Este método consiste primero en exponer y comparar los estudios y teorías que existen sobre un tema. Luego se coteja los puntos de vista similares y contradictorios antes de sacar conclusiones. Así, el análisis dialéctico parece un arte de construir conocimientos legítimos, un arte de presentar un estudio fidedigno y no partidista, alejado de las opiniones tajantes.

Optamos por esta dimensión dialéctica en un procedimiento constructivo, con los objetivos de enriquecer nuestro estudio y conferir a sus resultados un carácter convincente. La dimensión asertiva de este método nos permite presentar de modo imparcial las manifestaciones del empoderamiento y de la ginecocracia en las obras corpus de nuestro estudio. La dimensión antitética nos ayuda a identificar los límites posibles de esas informaciones y los de nuestras propias aserciones de inicio a nuestro estudio, para depurarlas de las eventuales subjetividades que quepan. Y, por fin, la dimensión sintética nos facilita resultados fidedignos y exhaustivos.

\section{Las técnicas de análisis de contexto y contenido}

Antes de concluir esta rúbrica sobre los enfoques metodológicos, hace falta notar que los métodos objetivo, comparativo, analítico y estético, nos parecen fundamentales en el marco de nuestro estudio, que compete a la literatura y por razones que expusimos con anterioridad a esta parte. A pesar de ser los fundamentales, esos métodos no son los únicos de los que hacemos uso.

En efecto, en nuestros análisis, utilizamos a título subsidiario también, al lado de esos principales métodos, algunas técnicas de análisis de contextos y contenidos.

El análisis de contexto consiste en situar un documento en su contexto (género, fecha, procedencia, situación histórica, condiciones de creación o de redacción). También nos permite precisar explícitamente el contenido del documento, definir una problemática a partir de una idea central y analizar las palabras y nociones que revisten una importancia histórica, los giros estilísticos y los tonos.

(Boutillier, S.; Goguel D'Allondais, A. y al. Óp. Cit., págs.163-164).

Elegimos las técnicas de análisis de contextos y contenidos como método de trabajo, porque necesitamos apreciar el empoderamiento y la ginecocracia en cada uno de los contextos históricos de las obra por una parte, y por otra, en nuestro propio contexto socio cultural.

\section{Presentación de los autores y sus obras \\ 4.1 Presentación de los autores \\ 4.1.1 María de Zayas Sotomayor}

Poco se conoce de su biografía. Sólo puede afirmarse con certeza que nació en el seno de una familia madrileña de origen noble y elevada posición social. Fue bautizada en Madrid, el 12 de septiembre 1590 y su madre fue María Barraza. Su padre, Fernando de Zayas, era capitán de infantería y poseía el hábito de Santiago. María de Zayas y Sotomayor fue una célebre escritora española del Siglo de Oro cuya obra se siguió publicando durante el siglo XVIII. Sin embargo, su vida, como la de tantas otras escritoras contemporáneas suyas, no se consideró relevante para ser publicada, razón por la que se carece de los datos necesarios para una biografía completa. Pero no hay certeza respecto al lugar y fecha de fallecimiento pues, aunque existen dos partidas de defunción a nombre de María de Zayas, una del 19 de enero de 1661 y la otra de 26 de noviembre de 1669, ninguna corresponde a la de la novelista. Su padre fue capitán de infantería, sirvió como caballero al conde de Lemos, razón por la cual se supone que la familia Zayas debió seguir al Conde en su virreinato de Nápoles. En 1628 obtuvo el hábito de la Orden de Santiago, lo que significa, entre otras cosas, que la familia perteneció a la nobleza menor y que Zayas conocía las reglas de esta Orden monástica. Otros lugares donde se cree que residió son Zaragoza, porque allí se publica parte de su obra, Sevilla o Granada. Asimismo se supone que vivió en Barcelona, si bien este dato está respaldado por las investigaciones que realizó Brown Kenneth en torno al Vexamen de 15 de marzo de 1643 del poeta barcelonés Francesco Fontanella de donde Kenneth deduce que la escritora residió en Barcelona en 1643. Otros datos relativos a la publicación de algunas obras, le llevan a afirmar que regresó a Barcelona 1648, para allí negociar la reedición de sus narraciones, o bien que nunca se marchó.

Por su parte, María José Martínez indica la posibilidad de que María de Zayas y Madame de Sévigné se hubieren conocido porque las novelas de Zayas fueron traducidas y escandalosamente copiadas por el poeta Scarron, primer marido de Madame de Maintenon, futura esposa morganática de Luis XIV, quien mantenía una excelente amistad con la marquesa.

Sobre la base de que en toda obra literaria hay datos autobiográficos del autor, los estudiosos de la obra de María de Zayas deducen aspectos de su carácter, personalidad, experiencias personales, creencias religiosas e incluso identidad y orientación sexual. Todo esto gira en torno a un mismo eje: el feminismo pre moderno, la actitud feminista de Zayas. Así, hay quienes deducen

Page | 185 
de lo que consideran datos autobiográficos que, lo que mueve a la autora, es bien un desengaño personal, un anti machismo, o una ideología feminista. Por su parte, quienes investigan la genealogía del feminismo, hacen una crítica literaria desde la perspectiva feminista, señalando la denuncia que hace la autora de la opresión que sufren las mujeres y del trato que reciben de los hombres.

El estilo realista y picaresco, abundante en reivindicaciones feministas y pinceladas eróticas, ha hecho de la obra de María de Zayas y Sotomayor un auténtico punto y aparte en el panorama literario del Siglo de Oro.

Por estar al servicio del conde de Lemos, la familia se vio obligada a continuos traslados que se reflejaron en la obra de María. Así, por ejemplo, la recurrencia del tema italiano, fruto de su estancia en Nápoles cuando el conde de Lemos desempeñó allí el cargo de Virrey. Igualmente se deduce su estancia en Zaragoza del hecho de haber publicado allí la primera parte de sus Novelas ejemplares y amorosas (1637), a la que siguió, diez años más tarde y ya en Madrid, Parte segunda del sarao y entretenimiento honesto (desengaños amorosos). Ambos volúmenes fueron recopilaciones de relatos de tema amoroso, escritos en un tono brioso y apasionado, en los que evitó la retórica y el uso excesivo de culteranismos.

Las anécdotas sobre las que basó la acción tienen tono moralizante y fueron reivindicadas por la autora como verídicas. En estas novelas subyace un propósito común: denunciar las limitaciones que para la mujer representaban la moral y los usos sociales del siglo XVII. Por ello, María de Zayas fue considerada por la crítica literaria del XIX, y muy especialmente por Emilia Pardo Bazán, como la mayor feminista de las letras españolas. Sus protagonistas son mujeres de carácter fuerte, decididas, que ceden ante el impulso amoroso no tanto por una mera atracción sexual como para ejercer un acto de libertad individual.

Es evidente la influencia de Boccaccio en el esquema general de la obra y en la complacencia realista de la narración, donde está muy acentuado, en comparación con el modelo italiano, el carácter aristocrático de los personajes; pero más cercano a la autora es el modelo de las Novelas ejemplares de Miguel de Cervantes (del que repiten el título), especialmente cuando sus narraciones asumen actitudes moralizadoras. Las novelas tuvieron en seguida una gran resonancia. Traducidas en parte al francés, en 1656, por un tal Methel, que parece ser d'Ouville, fueron imitadas por Paul Scarron, que insertó tres de las novelas en una colección suya y una cuarta en la Novela cómica. María de Zayas escribió, además, una única obra para teatro, la comedia La traición en la amistad (hacia 1639), que fue elogiada por Lope de Vega en El laurel de Apolo.

\subsubsection{Tirso de Molina}

No poseemos los caudalosos datos que rodean a Lope de Vega, ni los certeros y definitorios de Cervantes, Mateo Alemán o Calderón. Esta realidad ha provocado que se hable a veces de "enigma biográfico" (Chabás, Juan, 1962:208). De todos modos, digámoslo pronto y aprisa, se trata de una biografía que no tiene hitos de deslumbrantes acaeceres o de llamativas actividades. La vida de Tirso es, sin más, la de un fraile sagaz y consciente que cumple dignamente con los cometidos que su Orden le encarga. Desempeña puestos importantes en su regla y además, escribe. Deja de escribir cuando las circunstancias se lo aconsejan u ordenan.

Uno de los problemas que se planteaba con nuestro escritor era el de fijar la fecha de su nacimiento. Saltando por encima pareceres, opiniones y fantasías, diremos que la última palabra, hasta ahora, parece ser la del padre Luis Vázquez, también tirsista fervoroso. El padre Vázquez ha estudiado un documento, conocido ya hace tiempo, del archivo de la parroquia madrileña de San Sebastián. Este documento autoriza a pensar en 1579 como el del nacimiento de Tirso: «Gabriel Téllez nació en 1579. Nuevos hallazgos documentales, en homenaje a Tirso » (Vázquez, Luis, 1981: 19-36). A partir de este instante, y pensamos que el vivo interés actual de la Orden por su antiguo e ilustre miembro aún nos dará frutos importantes, disponemos de un repertorio de fechas concretas que nos sitúan a Fray Gabriel Téllez sobre la tierra de la monarquía española, en diversos lugares de España y en Santo Domingo, ya en tierra americana.

Para ordenar los datos biobibliográficos de Tirso, valgámonos de los estudios de Berta Pallares en sus ediciones de La huerta de Juan Fernández (Pallares, Berta, 1982: 271) y La villana de Sagra (Pallares, Berta, 1984: 72). Según dichas ediciones, Tirso entra en 1600 como novicio en el convento de la Merced, en Madrid. El noviciado lo termina en la casa de Guadalajara el año siguiente. Entre 1601 y 1610 efectúa estudios universitarios. Le encontramos en Salamanca cursando Artes, de 1601 a 1603 . Entre 1603 y 1607 estudia Teología y Sagrada Escritura en Guadalajara y Toledo. Asiste a la Universidad de Alcalá entre 1608 y 1610 (ya es vicario del convento de Soria). Y se ordena presbítero en Soria (o en Burgo de Osma). En 1610 podemos dar por finalizados los años de formación universitaria (fray Gabriel Téllez tiene treinta y un años) y comienza a producir. Vive en el convento de Madrid hasta la primavera de 1611, en que va a Toledo. Allí estará hasta finales de 1615. Podemos decir, de modo casi simbólico, que este tiempo toledano se abre con La villana de la Sagra, de 1611, y se cierra con Don Gil de las calzas verdes, de 1615. A fines de este último año llena una corta etapa en el convento de Soria. 
Como vemos, su vida, en lo que tiene de propia escenificación, se mueve dentro de la Orden: capítulos, cargos, viajes de un convento a otro. La actividad de escritor aparece disimulada, casi como cultivada con cierto pudor, lejos del bullicio estrepitoso de tertulias, grupos, cenáculos. En1616, a finales del verano, embarca en Sevilla, camino de La Española: « Tirso de Molina, pasajero a Indias », delata Nolasco en sus Estudios (Nolasco P., 1949: 197). En esta embarcación, existe cédula real, dada por Felipe III, autorizando el viaje al padre Juan Gómez, al que acompañan varios frailes. Entre ellos va fray Gabriel Téllez, predicador y lector, de edad de treinta y tres años. De este viaje procederán los datos, leyendas, noticias fabulosas o exactas sobre América que, a veces, saltan en sus versos.

Al regresar a la península en 1618 , le encontramos como definidor general de la provincia de Santo Domingo, en el capítulo de Guadalajara. Terminado éste, y tras un breve paso por Madrid, vuelve a Toledo donde permanecerá en el convento de Santa Catalina: es el momento en que inicia la redacción de Los cigarrales que no aparecerán hasta 1624. Entre 1618 y 1620 , explica Teología en Segovia.

En 1620, ya la cuarentena encima, Tirso está en la cumbre de su fama como dramaturgo. Sin abandonar, en manera alguna, sus obligaciones con la Orden (Capítulo general en Zaragoza, 1622: Capítulo provincial en Burgos, 1623; Comendador del convento de Trujillo, 1626-1629: Capítulo provincial en Guadalajara en este año; una corta visita al convento de Conjo, en Santiago de Compostela, en 1630; conventual de Toledo desde mediado 1630 hasta entrado 1632, período en el que escribirá Deleitar aprovechando), comienza la preparación de las Partes de comedias: sale la Primera en 1627. En junio de 1622, Tirso participa, con gran fortuna, en uno de los más ruidosos hechos literarios del tiempo: Madrid se cubrió de galas y entusiasmos para celebrar la canonización de San Isidro, su santo patrón. Uno de los actos celebrados con este motivo fue una justa poética, en la que hubo multitud de premios. Tirso envió cuatro octavas sobre los celos de San Isidro y cuatro décimas. No logró premio alguno. El de las décimas fue para Mira de Amescua y el de las octavas para Guillén de Castro. Al año siguiente, 1623, Tirso aprueba los Donaires del Parnaso, de Alonso del Castillo Solórzano, 1624, y da su aprobación a Experiencias de amor y fortuna, de Francisco de las Cuevas. Parece que acudía por este tiempo a la Academia poética de Sebastián de Medrano. En 1624 aparecen versos suyos en los preliminares del Orfeo, de Pérez de Montalbán, y en el Oficio del príncipe cristiano, de Belarmino, traducido por Miguel de León Suárez. En 1625 tuvieron lugar los tropiezos con la Junta de Reformación. La Junta de Reformación fue fruto de la llegada al trono de Felipe IV, deseoso de sanear la administración. La Institución Real consideraba fin esencial de la Junta «la reformación, no sólo en esta Corte, sino en estos mismos reinos y señoríos, en materia de vicios, abusos y cohechos » (Palenca González, Ángel, 1932: 455). La Junta comenzó a actuar en 1624. Entre los escritores que provocaban el escándalo de los graves miembros de la Junta está Quevedo (se habla de amancebamiento con una tal Ledesma, con la que, dicen, tenía hijos), y está nuestro Tirso de Molina. La Junta se declaró abiertamente en contra de las representaciones teatrales. Pretendió que se prohibiese la asistencia de los religiosos a los corrales y a los toros. Procuró que se limitase el número de compañías y de teatros... Un acuerdo de 6 de marzo de 1625 se refiere a Tirso:

Maestro Téllez, por otro nombre Tirso, que hace comedias. Se trató del escándalo que causa un fraile mercedario, que se llama el Maestro Téllez, por otro nombre Tirso, con comedias que hace profanas y de malos incentivos y ejemplos. Y por ser caso notorio se acuerda que se consulte a S.M. de que el Confesor diga al Nuncio le eche de aquí a uno de los monasterios más remotos de su Religión y le imponga excomunión mayor latae sententiae para que no haga comedias ni otro ningún género de versos profanos. Y eso se haga luego (Palenca González, Ángel, 1945: 84).

Es evidente que Tirso redujo su actividad creadora y se centró en la publicación de sus producciones anteriores. No obstante, se han podido fechar algunas comedias durante los años de malestar. Tuvo que afrontar un corto confinamiento en la casa de Cuenca. Que parece consecuencia de una visita canónica llevada a cabo por el padre Marcos Salmerón, quien, a su vez, era enemigo personal de Tirso. El resultado de la visita era tajante en algunos aspectos: los religiosos no podrían tener en su celda libros profanos de comedias ni de poesías, y se les conminaba a deshacerse de ellos en un plazo de veinticuatro horas. Igualmente prohibía a los religiosos escribir coplas o documento alguno contra el gobierno público. (Acta del 20 de septiembre de 1640 ). (Zamora Vicente, Alonso, Tirso de Malina, 1949: 16). Si Tirso no obedeció totalmente la prohibición, sí, por lo menos, disminuyó notablemente su labor literaria. Probablemente, La huerta de Juan Fernández es de 1626, y existe el autógrafo, firmado y fechado en 1638, de Las quinas de Portugal.

En 1623 es cronista de la Orden. Entre este año y 1636, es definidor de la Orden y provincial de Castilla, lo que le obliga a residir en Madrid. Fueron apareciendo las sucesivas Partes de comedias: 1632, la Tercera (antes que la segunda), impresa en Tortosa. En 1635, la Segunda y la Cuarta, y en 1636 la Quinta (en Madrid las tres). Y esto sin perder de vista las actividades religiosas: en 1627 alcanzó el grado de Maestro y en 1639 luce esta condición en el Capítulo general de Guadalajara. 
Ya le tenemos por 1640 sesentón, voz de la experiencia dentro de la Orden y alejado de la escena del mundo. Continúa de cronista y alejado de la escena del mundo proyecta vidas de santos, de personajes de la Orden y asuntos similares. Entre 1640 y 1643, en que sabemos de un nuevo período toledano, en el convento de la Orden, no podemos decir nada de su actividad, ya que el toledano convento mercedario de Santa Catalina, desaparecido, fue construcción medieval de los siglos XIII al XIV. La advocación de Santa Catalina fue decisión del arzobispo Tenorio. El Monasterio sufrió la ocupación napoleónica y la desamortización posterior le dio golpe definitivo. Sobre sus ruinas se levantó una cárcel. Algunos de sus elementos decorativos pasaron al museo provincial. En 1645 Tirso es nombrado Comendador de Soria. Por fin, como nos lo facilita un documento, el registro de misas del convento de Segovia, con fecha 24 de febrero de 1648, hubo un funeral en su recuerdo: "Se hizo el ofrecimiento por el padre Maestro Téllez, que murió en Almazán » (Penedo, Manuel, 1949: 99).

\subsection{Presentación de las obras (Resumen, forma, estructuración, temas y breve comentario) 4.2.1 Novelas amorosas y ejemplares de María de Zayas Sotomayor Resumen}

Principiadas en 1637 y finalizadas en 1649, las Novelas amorosas y ejemplares son narradas en una reunión de nobles damas y caballeros, al estilo italiano del Decamerón de Giovanni Boccaccio, para amenizar las veladas navideñas. La obra se inicia con la presentación de la elegante y refinada casa de la aristócrata Lisis que da cobijo a cinco hermosas mujeres (Lisis, Lisarda, Matilde, Nise y Filis) y cinco galanes varones en Madrid. Para entretener a Lisis enferma de fiebre intermitente llamada cuartana, organizan un sarao -tertulia festiva- durante la cual se cuentan historias maravillosas, se interpretan piezas de música y se baila, se cena, se representa algún entremés y se recitan poemas líricos durante varias noches. Al contrario del ambiente ameno de esta primera parte, se relatan a continuación desengaños en el contexto simbólico de las fiestas de Carnaval, es decir, en el festejo de las máscaras o falsas apariencias. Las mujeres toman la palabra para expresar sus quejas, hacerse oír en una sociedad violenta, injusta y sorda a sus necesidades, defender su autonomía -tomando conciencia de su pasividad para recuperar o vengar su honor- y decidir de su destino, sea entrar en un convento o casarse con quien ella escoge o acepta. Con el tiempo y los encuentros, un tal Don Juan, amante atractivo de Lisis, se enamora de Lisarda, amiga de Lisis. La obra desenlaza en los amores de Lisis, quien, a pesar suyo, opta por casarse con su paciente pretendiente don Diego. Pero, acaba por renunciar al amorillo por Don Diego, para ingresar finalmente un convento, acompañada de su madre y su prima doña Estefanía.

\section{Estudio de la forma}

Las Novelas amorosas y ejemplares se integran en el género de la novela corta que tanto éxito tuvo en las letras españolas del siglo XVII, sobre todo a partir de la edición de las Novelas ejemplares de Miguel de Cervantes en 1613. Las similitudes entre las diez Novelas amorosas y ejemplares de María de Zayas, y las doce de Cervantes, están en la coincidencia del título y en el interés por criticar comportamientos o valores sociales que perjudican a la mujer. Además, los dos autores se inspiran de la tradición de los Novellieri italianos.

Del Decamerón de Giovanni Boccaccio toma la fórmula de una reunión por culpa de una enfermedad (en vez de la peste, unas cuartanas de Lisis) a lo largo de cinco noches, en cada una de las cuales se narran dos novelas de gran crudeza. Al contrario que otros novelistas contemporáneos suyos, no pretende exhibir un ingenio cortesano complicando el estilo ni hacerse pasar por moralista sermoneadora, sino que le interesan la amenidad narrativa, la psicología de los personajes y los ambientes en que se mueven. Además, en sus denuncias de injusticias indignantes reflejan independencia y recio orgullo femenino, sin mostrarse pacata en las escenas escabrosas.

El estilo de María de Zayas rehúye los excesos retóricos propios del culteranismo, tal como declara en la última novela de Desengaños amorosos:

Yo, como no traigo propósito de canonizarme por bien entendida, sino por buena desengañadora, es lo cierto que, ni en lo hablado ni en lo que hablaré he buscado razones retóricas ni cultas, porque además de ser un lenguaje que con extremo aborrezco, querría que me entendiesen todos, el culto y el lego (...) Y así he procurado hablar en el idioma que mi natural me enseña y deprendí de mis padres, que lo demás es una sofistería en que han dado los escritores por diferenciarse de los demás, y dicen a veces cosas que ellos mismos no las entienden. ¿Cómo las entenderán los demás sino en diciendo, como algunas veces me ha sucedido a mí, que, cansado el sentido por saber qué quiere decir y no sacando fruto de mi fatiga, digo: "Muy bueno debe de ser, pues que yo no lo entiendo".

Joan Pere Fontanella poeta del Barroco catalán, leyó un Vexamen, una sátira literaria en verso, para una de las actividades organizadas por la Academia de Santo Tomás de Aquino, de Barcelona. Siguiendo la costumbre, el poeta debía crear un mundo fantástico que fuera el pretexto para poder luego satirizar a los socios e invitados. En esta ocasión, los ridiculizados fueron los poetas contemporáneos de Fontanela, María de Zayas estaba entre ellos. Kenneth Brown asegura que el poeta tenía mucha 
confianza con María de Zayas para ofenderla tan impunemente. Si lo contrario fuera verdad, tales conceptos serían de demasiado mal gusto.

Lope de Vega la elogia en la silva VIII de su El laurel de Apolo, a lo que ella correspondió homenajeándolo en un soneto. Sibila de Madrid la Ilama en La Garduña de Sevilla Alonso de Castillo Solórzano:

En estos tiempos luce y campea con felices lauros el ingenio de doña María de Zayas y Sotomayor, que con justo título ha merecido el nombre de Sibila de Madrid, adquirido por sus admirables versos, por su felice ingenio y gran prudencia, habiendo sacado de la estampa un libro de 10 novelas que son 10 asombros para los que escriben deste género, pues la meditada prosa, el artificio dellas y los versos que interpola, es todo tan admirable, que acobarda las más valientes plumas de nuestra España

Durante largo tiempo, oscurecida por la crítica, Emilia Pardo Bazán reivindicó su obra, definida como picaresca de la alta sociedad del Siglo de Oro. Doña Emilia Pardo Bazán citaba algunos pasajes suyos sobre su feminismo:

En la era que corre estamos con tan adversa opinión con los hombres, que ni con el sufrimiento los vencemos ni con la conciencia los obligamos. (...) ¿Por qué, vanos legisladores del mundo, atáis nuestras manos para la venganza, imposibilitando nuestras fuerzas con vuestras falsas opiniones, pues nos negáis letras y armas? ¿Nuestra alma no es la misma que la de los hombres? (...) Por tenernos sujetas desde que nacimos, vais enflaqueciendo nuestras fuerzas con temores de la honra, y el entendimiento con el recato de la vergüenza, dándonos por espadas ruecas, y por libros almohadillas.

El trágico final de la mayoría de los «desengaños» influirá en el desenlace de los amores de Lisis, quien había optado por casarse con su paciente pretendiente don Diego pero, finalmente, querrá ingresar como -seglar- en un convento acompañada de su madre y su prima doña Estefanía. Esta decisión es considerada acertada por la voz narradora y reflejaría la situación social que limitaba a la mujer del siglo XVII a escoger entre un matrimonio -muchas veces impuesto- o una vida -con cierta autonomía- en los claustros religiosos donde las mujeres podían vivir sin profesar los votos:

Ya, ilustrísimo Fabio, por cumplir lo que pedistes de que no diese trágico fin a esta historia, la hermosa Lisis queda en clausura, temerosa de que algún engaño la desengañe, no escarmentada de desdichas propias. No es trágico fin, sino el más felice que se pudo dar, pues codiciosa y deseada de muchos, no se sujetó a ninguno (María de Zayas, 1993, 510)

María de Zayas aporta al género del relato breve una serie de rasgos característicos como: otorgar relieve al elemento extraordinario o fantástico, recrear escenas violentas, dar importancia al componente erótico con especial atención a los deseos sexuales femeninos $y$, sobre todo, eludir los finales felices que culminan en boda. Sus novelas suelen ver en el matrimonio el comienzo de una vida desgraciada para las mujeres, quienes deben enfrentarse a una sociedad hostil con su género; es decir, las narraciones de Zayas rebaten o «distorsionan» la ideología que subyace a la novela corta del Barroco (María de Zayas, 2010: 36).

María de Zayas defiende ante todo que la mujer no es el ser malintencionado y pérfido a quien los moralistas, teólogos y algunos humanistas se empeñaban, desde siglos atrás, en acusar de todos los males, sino que, como todo ser humano, es capaz de valientes acciones y honestos comportamientos. Por eso, elle se alza contra ideas misóginas (en ocasiones, enmascaradas bajo una sátira anti petrarquista) como las de Baltasar Gracián, que expuso en El Criticón: «Pues las mujeres, de pies a cabezas una mentira continuada, aliño de cornejas, todo ajeno y el engaño propio». Francisco de Quevedo, en la parte El mundo por de dentro que integra su obra filosófica Sueños y discursos de verdades descubridoras de abusos, vicios y engaños en todos los oficios y estados del mundo, llegó a decir:

las mujeres lo primero que se visten, en despertándose, es una cara, una garganta y unas manos, y luego las sayas. [...] Las cejas tienen más de ahumadas que de negras; y si como se hacen cejas se hicieran las narices, no las tuvieran. [...] ¿Qué cosa es ver una mujer, que ha de salir otro día a que la vean, echarse la noche antes en adobo, y verlas acostar las caras hechas cofines de pasas, y a la mañana irse pintado sobre lo vivo como quieren?

(Quevedo, 1972:177) 
Precisamente, Zayas acusará a los hombres de limitar la existencia de las mujeres a vivir encerradas en el ámbito doméstico, y obsesionadas por su honra y por el acicalamiento excesivo. Todo ello destina a la mujer a vivir preocupada por las apariencias y a desarrollar comportamientos hipócritas o engañosos. La escritora considera que la sociedad tendría que abrir el horizonte de expectativas a las mujeres para que pudieran cultivar su intelecto y decidir su destino social. De esta manera, se mejorarían las relaciones entre hombres y mujeres y se evitarían matrimonios forzados, engaños de las mujeres por proteger su honra, muertes de esposas por maltrato físico y psicológico y, en términos generales, la infelicidad a la que se ven determinadas las personas nobles de su sociedad.

\section{Estructuración, temas y comentario}

Las Novelas amorosas y ejemplares constituyen un grupo de diez novelas cortas. La autora publicó la primera parte o Decamerón español en1637, y la segunda en 1647. Éstos son los títulos:

- Aventurarse perdiendo
- La burlada Aminta
- El castigo de la miseria
- El prevenido engañado
- La fuerza del amor
- El desengaño amando
- Al fin se paga todo
- El imposible vencido
- El juez de su causa
- El jardín engañoso

En ellas se desarrollan temas tales como la nobleza, la feminidad, el feminismo, el honor, el recato de la mujer, la libertad, la instrucción científica, la moral, la falocracia, la discriminación sexual, el género o el empoderamiento, la sexualidad, el amor, los engaños, la picaresca, la cosificación de la mujer, la religión, entre tantos otros. Pues, las Novelas amorosas y ejemplares son muy ricas en didactismo.

María de Zayas Sotomayor pertenece a la clase aristocrática y plantea una visión muy tradicional de la sociedad, marcada sobre todo por el valor de la honra y culpa a los hombres de poner en peligro el buen nombre de las mujeres nobles.

En las Novelas amorosas y ejemplares, analiza los estratos sociales superiores de su época en la que se percibe influencia de Miguel de Cervantes. La novelista parece declarar que el hombre ha monopolizado el ámbito del saber para preservar su poder social. En el siglo XV, la religiosa Teresa de Cartagena ya había querido aclarar que el saber no era propiedad natural del hombre y, por tanto, la mujer podía demostrar capacidad intelectual si Dios lo deseaba. Para María de Zayas, «las almas no son hombres ni mujeres». Era muy aficionada a la lectura, como dice en el prólogo: «Al que leyere de Novelas amorosas y ejemplares: ¿Qué razón hay para que no tengamos prontitud para los libros? Y más si todas tienen mi inclinación, que en viendo cualquiera nuevo o antiguo dexo la almohadilla y no sosiego hasta que le paso». Por lo que, María de Zayas considera que prohibir el desarrollo intelectual a las mujeres es perjudicial para ellas, pero también para los hombres.

Es interesante, en este sentido, detenerse en una de las novelitas que integra la primera colección: El prevenido engañado, que refleja la huella cervantina. En este relato se narra la historia de don Fadrique, un noble caballero granadino, quien conocerá diversas mujeres que le desengañarán y le conducirán a buscar una esposa ingenua que pueda manipular.

La primera mujer de la que se enamorará es Serafina, una dama a quien Fadrique considera virtuosa hasta que descubre que ha abandonado a una niña recién nacida, que el caballero dejará al cuidado de una comadre con la petición de que sea llevada a un convento cuando tenga tres años. Tras este suceso, el protagonista conocerá a doña Beatriz, una aparente viuda honrada que aceptará casarse con él pasado el año de luto. Don Fadrique valorará ese gesto como reflejo de la honradez de la dama hasta que averigüe que mantiene relaciones sexuales con un negro que esconde en un aposento, y que vive cruelmente esclavizado para satisfacer la lujuria de su señora. Fadrique huirá a Madrid, donde conocerá a doña Violante, quien no mostrará ningún interés en casarse y acabará engañándolo con un joven mozo. En Nápoles se relacionará con una esposa adúltera y en Roma llegará a matar al marido de otra dama con la que había trabado amistad. Tras varios años de desventuras sentimentales, decidirá volver a España. Se hospedará en casa de una duquesa valenciana con la que hablará acerca de su búsqueda de una esposa ingenua para no ser de nuevo burlado; la interlocutora le comentará que una mujer discreta es preferible porque es más consciente de sus actos, y le mostrará de qué es capaz una mujer ingeniosa para divertirse y proteger su honra. Escarmentado, don Fadrique llegará a Granada y decidirá casarse con Gracia, la niña que dieciséis años atrás había mandado educar en un convento. Creyéndose astuto, impondrá 
una peculiar vida de casados para asegurarse la fidelidad de su ingenua esposa: cada noche, Gracia vestirá una armadura para velar a su marido mientras duerme. Desafortunadamente para el manipulador esposo, un gallardo caballero cordobés descubrirá a Gracia una mejor vida de casados que la joven confesará sin ningún sentimiento de culpabilidad porque su necedad se lo impide. De esta forma, el relato muestra cómo la ingenuidad de la joven ha sido la que ha facilitado el adulterio y el posterior desenlace. Don Fadrique acabará sus días humillado y solo; Gracia ingresará en el mismo convento donde se halla su madre Serafina y hará construir otro espacio sagrado en el que puedan recluirse más mujeres.

Las palabras que cierran el relato muestran la intención moral que pretende la obra: «En fin, don Fadrique, sin poder excusarse, por más prevenido que estaba, y sin ser parte las tierras vistas y los sucesos pasados, vino a caer en lo mismo que temía, siendo una boba quien castigó su opinión».

Entró doña Gracia monja con su madre, contenta de haberse conocido las dos porque, como era boba, fácil halló el consuelo, gastando la gruesa hacienda que le quedó en labrar un grandioso convento, donde vivió con mucho gusto. Y yo le tengo de haber dado fin a esta maravilla para que se avisen los ignorantes que condenan la discreción de las mujeres. Que donde falta el entendimiento no puede sobrar la virtud; y también que la que ha de ser mala no importa que sea necia, ni la buena, el ser discreta, pues siéndolo sabrá guardarse. Y adviertan los que prueban a las mujeres al peligro que se ponen (Zayas 2010, 340). Así que las mujeres deberían recibir la misma educación que los hombres.

En la presentación del Desengaño tercero, la narradora expone, tanto como lo haría también sor Juana Inés de la Cruz, que:

[...] la culpa de las mujeres la causan los hombres. Caballero que solicitas la doncella, déjala, no la inquietes, y verás cómo ella, aunque no sea más que por vergüenza y recato, no te buscará a ti. Y el que busca y desasosiega la casada, no lo haga [...]. Y el que inquieta a la viuda, no lo haga [...]. Y si las buscas y las solicitas y las haces caer, ya con ruegos, ya con regalos, ya con dádivas, no digas mal de ellas, pues tú tuviste la culpa de que ellas caigan en ella.

Podemos notar semejante postura en las redondillas de la escritora Sor Juana Inés de la Cruz:

\author{
Hombres necios \\ a la mujer sin razón, \\ sin ver que sois la ocasión, \\ de lo mismo que culpáis: \\ si con ansia sin igual \\ solicitáis su desdén, \\ ¿por qué queréis que obren bien, \\ si las incitáis al mal? \\ (Cruz 1983, 181-182)
}

José M. ${ }^{a}$ Roca Franquesa $(1976,308-309)$ ha sugerido que sor Juana hubiera podido ser influenciada por la lectura de la obra de Zayas: ambas atacarán el desigual rasero que juzga los comportamientos amorosos de hombres y mujeres y, además, alzarán su voz para pedir que las mujeres reciban una educación similar a la de los hombres. Sor Juana expondrá en un soneto:

En perseguirme, Mundo, ¿qué interesas?

¿En qué te ofendo, cuando sólo intento

poner bellezas en mi entendimiento

y no mi entendimiento en las bellezas?

Yo no estimo tesoros ni riquezas;

y así, siempre me causa más contento

poner riquezas en mi entendimiento

que no mi entendimiento en las riquezas

(Cruz, 1982:94)

En el Desengaño cuarto de María de Zayas, el personaje de Filis se lamenta de que los hombres, por miedo a perder su hegemonía social, pretenden que las mujeres se preocupen por su aspecto físico y olviden adornar su intelecto. Ella alega: 
y como en lugar de aplicarse a jugar las armas y a estudiar las ciencias, estudiar en criar cabello y matizar el rostro ya pudiera ser que pasaran en todo a los hombres [...] Y así, empezando a tener discurso las niñas, las ponen a labrar y hacer vainillas, y si las enseñan a leer es por milagro, que hay padre que tiene por caso de menos valer que sepan leer y escribir sus hijas, dando por causa que de saberlo son malas, como si no hubiera muchas más que no lo saben y lo son, y esta es natural envidia y temor de que los han de pasar en todo.

María de Zayas Sotomayor parece lamentar que el hombre haya monopolizado el ámbito del saber para preservar su poder social. En el siglo XV, la religiosa Teresa de Cartagena ya había querido aclarar que el saber no era propiedad natural del hombre y, por tanto, la mujer podía demostrar capacidad intelectual si Dios lo deseaba.

Invariablemente, hay mujeres que acaban mal por la liberalidad con que se entregan; pero no son todas. Es también notable lo poco que miran al decoro personal o familiar cuando siguen sus impulsos, que es casi siempre. Al hilo de diálogos sobre los distintos narradores en torno a la discreta Lisis, María de Zayas crítica con la misma libertad que muestran sus personajes las idea de la época acerca de la honra y la virtud, que, en su opinión, tanto perjudicaban a las mujeres. Así, en una frase que recuerda las de Sor Juana Inés de la Cruz, dice Lisis a un galán que proclamaba su deseo de encontrar mujer tonta y honrada:

«Y ¿cómo sabrá ser honrada la que no sabe en qué consiste el serlo?»

De la burla picaresca, abonada al tremendismo, que domina la primera serie novelesca, pasa en la segunda al motivo barroco por excelencia: el Desengaño, que es a veces notación de la injusta burla de las mujeres por los hombres y, en otras, expresión dolorida y casi metafísica de la imposibilidad de los sexos para vivir lealmente y en armonía, tan distintas son las fuerzas que los gobiernan. En La esclava de su amante, La inocencia castigada, El verdugo de su esposa o Mal presagio casar lejos, un hado siniestro domina las vicisitudes amorosas. De la carcajada en El castigo de la miseria se pasa a la melancolía y el pesar de Estragos que causa el vicio, última narración y despedida aparente de la autora. No hay dignidad en el amor:

¿Qué más desengaño aguardáis que el desdoro de vuestra fama en manos de los hombres?(...) ¿Es posible que con tantas cosas como habéis visto y oído no reconozcáis que en los hombres no dura más la voluntad que mientras dura el apetito, y en acabándose, se acabó?

En Desengaños, además de tratar la belleza conforme a los cánones del preciosismo, María de Zayas hará decir a una de las narradoras, Lisis, pues no hay duda que si no se dieran tanto a la compostura, afeminándose más que naturaleza las afeminó, y como en lugar de aplicarse a jugar las armas y a estudiar las ciencias, estudian en criar el cabello y matizar el rostro, ya pudiera ser que pasaran en todo a los hombres. Lisis entra en un convento al final de las novelas y por ello muchos de sus críticos y editores han supuesto que ése fue el destino último de doña María. Azorín se la imaginaba en una buhardilla madrileña, mirando los tejados lluviosos y los gatos vagabundos.

Como narradora le caracteriza una gran fuerza y es de una frescura y novedad sin precedentes ni tampoco epígonos. Tiene de su época el gusto por la violencia, la crueldad, la magia y los encantamientos. La moral en ella no es moraleja sino escarmiento. Ni ahorra episodios picarescos cuya crudeza no desmerece del Buscón_quevedesco, ni queda atrás en el cultivo de la novela bizantina a la Cervantina en otros como La fuerza del amor o El prevenido engañado. Pero quizás lo que más sorprende en ella es la desenvoltura con que se comportan los personajes femeninos en el aspecto sexual y amatorio. Desde la que persigue a un hombre que ve por el balcón hasta la que guarda un amante negro en el establo hasta devorarlo sexualmente, antes de infinitos adulterios. No en vano en el XVIII, la Inquisición prohibió reeditar sus novelas.

Total, María de Zayas avisa a las mujeres sobre los engaños de los hombres, las alienta a instruirse, a embellecerse, a disfrutar de su feminidad y de su vida. Además, ella denuncia los abusos que ejercen los hombres sobre las mujeres, por lo que ella se hace autora feminista, según nosotros.

\subsubsection{La prudencia en la mujer Resumen}

Muerto el Rey Don Sancho el Bravo, su esposa doña María viene a ser reina, de ser menor de edad su hijo Fernando. Los infantes don Enrique, don Juan, juntos con don Diego de Haro, empiezan a codiciar el trono y a la Reina María a quien quieren hacer esposa. Urden varios complotes para arrebatarle el trono. Primero inventan astucias para negárseles a la reina y a su niño su derecho a heredar el trono, declarando ilegítima la filiación de Fernando. Amotinan a la gente y secuestran a la reina y a su hijo. 
Son los poderosos parientes de la reina -don Juan Alonso Caravajal, don Pedro Caravajal y don Juan Benavides-quienes acuden a sacar a la reina y a su niño de este secuestro.

A pesar de este agravio que merece severos castigos, la Reina se los absuelve. De esta clemencia real, esos traidores fingen ser gratos lisonjeándola. Muy pronto después, reinciden su traición utilizando a un hebreo llamado Ismael para envenenar al niño rey, con pretexto de curarlo de su malestar. Por fortuna, la reina, guiada por el instinto maternal, se percata del complot de asesinato de su hijo. Con destreza y mucha cautela, detiene al pobre medicastro Ismael quien manifiesta turbios sospechables durante el interrogatorio al que ella le somete. Desconfiada, ella le obliga a probar la ponzoña, por lo que muere el hebreo. Antes de fallecer, el medicastro Ismael revela la identidad del conspirador asesinato: el infante don Juan. Sin publicar la noticia del asesinato fallido, con mucho recato y sigilo, la reina le hace vislumbrar la segunda ofensa de la que él es autor. Se turba y se escribe un juramento para servirla lealmente.

Con prudencia y comedimiento, la reina se mete en el juego de sus traidores alabándoles y fingiendo respetarlos. Así, no condena ni difama a don Juan sino que lo indulta, sin embargo lo manda vivir en la Mota de Medina, un monte en donde va a vivir como labrador durante diez años. Entre tanto, el niño rey se ha hecho mancebo y su madre le ha cedido el trono oficialmente para ir a descansar en una aldea. Durante un partido de caza en el monte, el mancebo rey se topa con su tío, el infante don Juan quien finge ser una víctima inocente de la maldad de la reina. Le cuenta al rey Fernando IV todo tipo de mentiras sobre su madre. La acusa de liviandad y de malversación de fondos, con el único objetivo de apoderarse del trono. El mancebo lo cree y manda que se haga presos a su madre y a sus seguidores. Turbado por las revelaciones difamatorias de don Juan contra su madre, el mismo Rey se lleva a la aldea donde descansa la reina y adonde se fueron don Juan y don Enrique para detenerla.

En la aldea, el Rey encuentra a don Juan con su madre. Ésta se lo revela todo -con pruebas indudables- sobre la traición y la deslealtad de don Juan y don Enrique. El Rey ofendido, manda que se los haga presos a todos los traidores. Pero la reina le disuade de ello y los absuelve de nuevo.

\section{Estudio de la forma}

En la obra La prudencia en la mujer, sobresalen la metáfora, la ironía y la sátira. Además de esas figuras de estilo, aparecen en menor medida la metonimia, la antítesis y la alegoría.

\section{La metáfora}

Ya en el verso 935 ( y soldando nuestras quiebras »), notamos el uso de la palabra "quiebras «para significar las "opiniones diferentes «que se manifiestan en el grupo de los traidores. Para nosotros, Tirso utiliza esta palabra -que remite a fallos o fisuras en algo, mientras que las diferencias de opiniones pueden resultar provechosas, o sea constructivas-porque quiere dar a entender que este personaje (el infante don Enrique) forma parte exclusiva de la negatividad.

En los versos 994-1002, se juega metafóricamente con la condena como un convite y la muerte como un frágil papel de letales efectos:

Don Juan:

Pues tiempo vendrá en que pague

la costa deste banquete,

cuando lleguen a aprecialle

con lanzas en vez de plumas

los que nuestro valor saben.

Don Enrique :

Dejádmela ver primero.

¡oh muerte fiera ! ¡ que bastes

a asombrar pechos de bronce,

sólo con un papel frágil! (VV. 994-2002)

A través de este juego metafórico, Tirso consigue sembrar en la memoria del espectador dos hechos que sucederán en los respectivos desenlaces de los dos actos siguientes: en la segunda jornada, doña María vuelve a quedar victoriosa de sus parientes sediciosos, sorprendiéndolos en una cena en la que se conjura contra ella. Y el desenlace final -como lo dijimos al estudiar el personaje (la reina doña María) - que restaura la honorabilidad de la reina ante su hijo y ante el reino, se produce por la habilidad de doña María, con un escrito que es, al mismo tiempo, la condena moral definitiva del infante don Juan.

En los versos 1006-1012, Tirso nos muestra por un lado la magnanimidad y confianza en sí y en la Providencia que tiene la reina $y$, por otro, juega con ellos como una advertencia premonitoria porque sabe de la reincidencia criminal de estos traidores hasta el último momento del drama: 
La reina doña María:

\author{
Contra vuestra alevosía, \\ en armas y en cortesía \\ os ha venido a vencer, \\ siendo hombres, una mujer, \\ a daros vida resuelta, \\ como quien la caza suelta \\ para volverla a coger. (vv. 1006-1012)
}

Por otra parte, la alusión que se hace metafóricamente a la caza se concretará en el contexto de la jornada tercera en la que don Juan intentará su nueva y última insidia contra la reina, durante la práctica cinegética del nuevo rey. Recordemos que Benavides había llamado a los traidores infantes « ambiciosos cazadores » (v.782).

Otro ejemplo de metáfora se nota en los versos 1373-1378:

Ismael: Muerte, bien os llaman trago,

pues sois purga que se bebe.

Pero la que receté

a costa de tantas vidas

en julepes y bebidas,

por el talión pagaré

La metáfora de la que se hace eco el personaje -la muerte como «trago »- designa el contratiempo de fallecer. Por otra parte es lógico que el médico judío asocie la inminente muerte que le espera con el trago del veneno que él mismo ha preparado (« purga que se bebe »). El pronombre «la » remite a « muerte ». El mismo personaje se hace eco de la mala fama de los médicos, como proverbiales agentes de la muerte, comentada en una nota anterior. "Julepe » es sinónimo de "jarabe" o "combinación" (todavía mantiene ese significado en el libro de prosa vanguardista de Giménez Caballero, Julepe de menta). Puesto que el médico judío va a aplicarse a sí mismo idéntico remedio letal que a tantos ha suministrado, se dice por tanto que responde al mandato clave de la famosa ley mosaica o Ley de Talión: « Ojo por ojo y diente por diente » (« Dentem pro dente, oculum pro oculo »).

\section{La ironía}

$\begin{array}{ll}\text { Luis: } & \text { Aquí está vuestra sentencia } \\ & \text { (Un papel en una fuente de plata) } \\ \text { Juan: } & \text { ¿Con ella el plato nos hace? } \quad \text { (versos 991-992) }\end{array}$

Irónicamente don Juan pregunta si la reina va a obsequiarlos con el manjar de su propia condena, al mostrárseles el texto de la misma servido en un plato.

La heroína doña María suele usar la ironía para aliviar o disminuir la gravedad de algunas situaciones o para burlarse de sus traidores:

La reina doña María:

La fama de quien me acusa, comparada con la mía, responder por mí podría sin otra prueba o excusa ;

(vv. 2163-2166)

Por la ironía, doña María intenta en esos versos quitarle la fama a quien la tiene deshecha totalmente por sus antecedentes remotos (Tarifa) y próximos (la complicidad con el judío homicida).

Más adelante, utiliza el mismo recurso lingüístico para revelar a su traidor sus defectos y con un tono burlesco:

La reina doña María:

Como en la mayor la cara retrata que en él repara; mas si en pedazos enseña las vuestras, viéndoos en él, como son tantas, don Juan, 
retratallas no podrán .

(vv. 3415-3420)

En esos versos, doña María utiliza la ironía para aludir a las muchas caras de don Juan que reflejarían los múltiples trozos en que se ha roto la carta. También alude a los engaños e hipocresía del personaje.

Al final de la obra, el mismo Tirso termina la pieza teatral así:

Con la segunda comedia

Tirso, senado, os convida

si ha sido a vuestro gusto ésta. (vv. 3677-3679)

La voz « senado » era el modo habitual de referirse al público del corral, con un término que fácilmente conseguía los efectos del halago. Para el Diccionario de Autoridades con la voz « senado » se designaba a «cualquier junta o concurrencia de personas graves, respetables » (Torres Nebrera, Gregorio, 2010: 286). Cabe también cierta jocosa ironía en su uso con motivo de halagar y de animar al público espectador.

\section{La sátira}

Esta figura de estilo que no se aleja tanto de la ironía -pero que más allá de ésta, reviste características burlescas y críticas a la vez-, está también presente en la obra de Tirso:

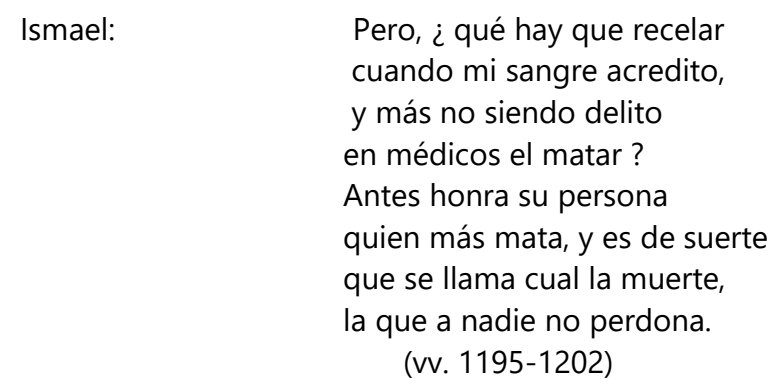

A través de esos versos, Tirso parece hacerse eco de las continuas sátiras contra los médicos, tan frecuentes en la época. Y esa sátira la asume el mismo personaje, que admite que los de su profesión tanta práctica tienen en matar a los demás que ellos mismos podrían llamarse « muerte ».

En otros versos, Tirso mezcla la ironía con la sátira:

$\begin{array}{ll}\text { Ismael: } & \text { Pero la que receté } \\ & \text { a costa de tantas vidas } \\ & \text { en julepes y bebidas, } \\ & \text { por el talión pagaré. } \\ & \text { Aunque en ser tantas, advierto } \\ & \text { que para que no me igualen, } \\ & \text { a media gota no salen } \\ & \text { los infinitos que he muerto. } \\ \text { (vv. 1375-1382). }\end{array}$

Los cuatro últimos versos de este parlamento culminan la autoironía del personaje en la tradicíón que combina lo antisemita y lo antigalénico. Prolonga esta autosátira en los versos inmediatamente siguientes, acompañando al suicidio inducido por la reina.

\section{La metonimia}

Es una figura retórica por la cual se puede expresar la causa por el efecto, el contenedor por lo contenido, el símbolo por lo significado. Por ejemplo: "Beber o compartir un vaso" para significar "Beber con otras personas la bebida contenida en el vaso"

Esta figura de estilo se nota en los versos:

Benavides: Vuestras gentes están rotas, 


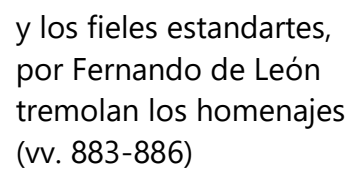

«Los estandartes fieles » es metonimia de los soldados leales a la causa de Fernando IV, ahora designado como « Fernando de León » (cuando lo era realmente de León y de Castilla) banderas que ahora tremolan desde las torres de homenaje de las diferentes fortalezas que han sido ganadas al infante don Juan.

\section{La antítesis}

Esta figura se mezcla con la ironía en estos versos:

Ismael: Si los que curando matan,
pagaran por donde pecan,
dieran menos que ganar
a los curas desde hoy.
(vv. 1385-1388)

La antitesis se nota a nivel de las palabras "curar" y "matar": se cura para la vida y se mata para la muerte. La vida y la muerte son antinómicas.

Por otra parte, si los médicos, que matan al decir que curan, cobraran estipendios por hacer esa labor mortífera, dejarían sin ingresos a los curas que ofician misas por las almas de los difuntos: una ironía ponderativa de lo muy letales que resultaban ser los galenos.

\section{La alegoría}

«Es una composición literaria o artística, cuyo sentido se basa en una ficción de este tipo y tiene generalmente un carácter didáctico o moralizante: La "Divina Comedia" de Dante es una alegoría de la vida del ser humano » (González, Maldonado, 2011: 83).

Esta figura retórica se nota en los versos:

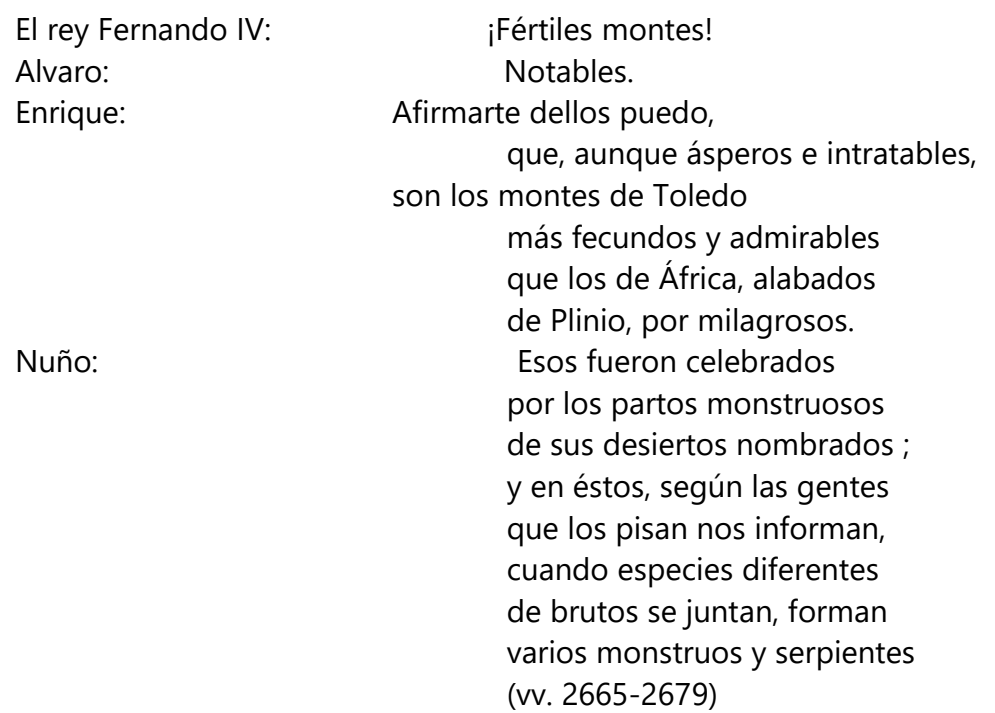

Las referencias casi maravillosas que hace don Enrique, todavía impresionado por los comentarios naturalistas de Plinio que se acaban de recordar, tienen también un alcance simbólico y anunciador de lo que va a ocurrir a continuación. Si según testimonio de los naturales de aquellos parajes, se pueden encontrar verdaderos monstruos por la fusión genética de dos brutos distintos, don Juan aparecerá poco después ante el rey fingiéndose desgraciado reo y leal a su señor, para introducir en el ánimo del joven monarca la monstruosidad de una serie de cargos graves contra la reina, presentándola a su vez como un auténtico monstruo contra su hijo. 
Por otra parte se habla también de «serpiente» y ése -rastrero y tentador-va a ser el comportamiento del personaje encontrado en el escenario de la caza. En vez de cazar este monstruo, el ingenuo Fernando se une a los lobos y va a la caza de su propia madre.

\section{Estructuración, temas y comentario}

La obra La prudencia en la mujer se reparte en tres jornadas en las que se desarrollan los temas de heroísmo, honor, política, buen gobierno, empoderamiento de la mujer o ginecocracia y recato.

Tirso de Molina escribe numerosos dramas históricos de tema aragonés, portugués, americano o castellano, de un ambiente realista, veteado de hechos maravillosos, ruidos de batallas y coloridas, descripciones, en los que proyecta figuras heroicas cuyas acciones responden a una finalidad dramática muy precisa: exaltar unas virtudes nacionales. En estas piezas no es lo fundamental el drama de la historia, pues su tema no es la historia como drama. Lo central en estos dramas es destacar, con ejemplaridad ideal, mediante las situaciones interesantes que la historia suministra, la dimensión heroica del pasado nacional. Por ello, los héroes de este teatro cambian de nombre, pero no de esencia, pues, en realidad, no hay más que un héroe: el heroísmo.

Dicen los críticos que la más famosa y la mejor de las piezas históricas de Tirso de Molina es la que estamos estudiando: La prudencia en la mujer. Doña María, protagonista del drama, reúne en sí la triple condición de gran reina, gran madre y gran mujer. El drama es la historia de su triunfo como reina, como madre y como mujer gracias a su recato frente a las intrigas de los poderosos que supeditan su acción política a su ambición de mando. La acción principal del drama está encomendada a dos personajes, que representan concepciones diametralmente opuestas del quehacer político: doña María y el infante don Juan. Doña María encarna ejemplarmente la concepción cristiana del poder; don Juan, no menos ejemplarmente, la concepción maquiavélica del poder. Para don Juan el fin justifica los medios. Para lograr el poder no duda en valerse de la calumnia y del asesinato, de la mentira y de la hipocresía. El conflicto resultante del choque de estos dos mundos permite al dramaturgo presentar las dos caras de toda realidad política: la ideal, sustentada por doña María y los fieles vasallos que la apoyan, y la real, sustentada por el infante don Juan y los nobles que lo secundan.

El drama es entonces, a la vez una lección y una denuncia, una apología y una crítica. Una lección y una apología de lo que debería ser la política (una buena gobernación, la justicia, la ética, la constancia, la fidelidad, la tolerancia, el respeto de la autoridad, la dignidad, etc.) y también del empoderamiento de la mujer o de la ginecocracia por medio del recato; y una denuncia y una crítica de la política maquiavelista (asesinato, calumnia, mentira, demagogia, corrupción, injusticia, abusos, etc.) y también de los desvíos y límites de la falocracia. Los caracteres están bien conseguidos, sobre todo el de doña María, cuya personalidad destaca poderosamente.

Lo que da vitalidad a esta comedia de Tirso y la confiere perenne vigencia es tanto lo acertado de la caracterización, como el ambiente en donde con gran fidelidad al espíritu del tiempo es traspuesto el sistema de usos y costumbres, la agudeza de ingenio, la ironía o la sátira, elementos valiosos cada uno por sí, pero también la calidad exclusivamente dramática, más allá de toda psicología y de toda verdad histórica, del mundo cómico logrado. La pieza es un universo cerrado y suficiente en sí mismo, cuya comicidad funcionará siempre eficazmente, por lo menos mientras existan espectadores capaces de percibir el juego dialéctico de cada individuo con el sistema de la colectividad a que pertenece.

Este drama tirsista ha contado casi con el unánime beneplácito de la crítica a lo largo de su recepción y valoración, al menos desde el siglo XIX. Ya el fino crítico que fue Alberto Lista, en las anotaciones con las que acompañó su edición del texto en Talía Española (1834), declaraba que era una de las comedias históricas en las que más parece haberse esmerado Tirso y, aludiendo a la recreación del personaje principal, el mismo erudito reconocía que su retrato ha sido comprendido por nuestro poeta de un modo admirable. Aquí nos la muestra valerosa, política, casta y honesta, sabia y prudente, levantando el trono de su hijo de entre las ruinas que formaron las facciones. Completaba estas consideraciones al reseñar la edición tirsista de Hartzenbusch (Teatro Escogido de Tirso de Molina, Madrid, 1839-1842) en sus Ensayos literarios y críticos en donde, al referirse a esta obra, encontraba como tacha « neoclásica » de la misma la radical ruptura de las reglas en su composición, concluyendo que este drama tirsiano se presenta tan mal arreglado como casi todos los de Tirso; pues la acción dura nada menos que catorce años, y el lugar de las escena recorre casi todos los pueblos que hay desde Toledo hasta Becerril. (LISTA, Alberto, 1844: 127).

El dramaturgo Gil y Zárate señalaba, en su Manual de Literatura, que era una de las comedias tirsianas que gozó de mayor popularidad en el siglo XIX, al tiempo que elogiaba el estilo poético y la eficacia de Tirso al pintar los caracteres singulares de su heroína. Sin embargo, otros críticos del mismo siglo como Mesonero, Martínez de la Rosa o Javier de Burgos la silenciaron, aun cuando admiraban profundamente la obra del mercedario. No así el crítico francés Viel-Castel, que volvió a destacar la originalidad de esta comedia y de su personaje central (Revue des Deux Mondes, XXIII, noviembre de 1840). Igualmente consideraba el alemán Von Schack que esta obra tirsiana era una de las más notables creaciones del teatro español, cuya apreciación coincidía con la de 
Menéndez Pelayo expresada en una nota al respecto publicada en La España Moderna de 1894, luego recogida en sus Estudios de crítica literaria:

Yo no tengo inconveniente en admitir que La prudencia en la mujer sea el mejor drama histórico de nuestro teatro, pero en todo lo demás del repertorio auténtico de Tirso no vuelve a encontrarse jamás la magnífica poesía del siglo XIV, que se respira en esta crónica dramática.

En 1990, el insigne hispanista francés Morel-Fatio elogiaba el lenguaje y el estilo de la obra, la construcción de su trama, el trazado de sus personajes, tanto mayores como menores. Consideraba que Tirso había elegido los aspectos históricos (o cronísticos) de la protagonista que mejor se adecuaban a su propósito artístico, que era dibujarla como madre, como viuda y como gobernante y advertía que el mercedario había introducido algunos elementos accesorios que no alteran la fisonomía verista de la noble reina. Semejante respeto con la historia tiene Tirso a la hora de afrontar la figura de Fernando el Emplazado, salvo que acentúa la diferencia entre el rey-niño de los dos primeros actos y el rey-adulto del tercero. Del intrigante don Juan, opina Morel-Fatio, que Tirso hace un refinado perverso, inventando alguna de sus asechanzas más teatrales como la de intentar el envenenamiento del heredero, y que, sin embargo, no se aleja demasiado del retrato que la tradición histórica nos ha dejado, si bien algo acentuada, en la maldad, por parte del mercedario. Los dos nobles leales a la legitimidad de Fernando, según la historia son un Haro y un Lara, Tirso los reduce a uno (Haro). Al segundo, lo alinea como un noble sin mayor importancia con los dos principales intrigantes. Respecto a los nobles Benavides y Carvajales, Morel-Fatio considera que Tirso debió de acudir a otras fuentes distintas a las de la crónica real, o ambos personajes actúan más en función de la imaginación del poeta. Así el Benavides que Tirso saca a la escena no es mencionado más que una vez por el cronista de Fernando IV, aludiendo al caballero asesinado en Palencia. También pudo acudir Tirso a los libros de Salazar y Mendoz o de Argote de Molina, como más adelante se señala.

En la época moderna fue doña Blanca de los Ríos la primera (y más apasionada) en elogiar la obra, considerándola como una glorificación de la Edad Media, y enfatizando el significado del personaje de doña María en una triple dimensión: heroica reina, noble esposa y abnegada madre (1910: 259-261). Y en la nota preliminar a la obra, en su edición del Teatro Completo de Tirso, doña Blanca añadía que en ella más que los hechos mismos nos interesa y atrae la historia de las almas; y el drama entero es la historia del alma de una mujer, de una heroica mujer " con tres almas », que en lucha abierta con reyes, infantes y magnates turbulentos y codiciosos que, como tempestad de hierro y furia, le asolaban sus estados, defendía jirón por jirón, hebra por hebra, el patrimonio de su hijo, y con aquellas hebras y jirones iba tejiendo la patria, la nacionalidad española (De los Ríos Blanca, 1946: 899-900).

Y el excelente conocedor de nuestro teatro áureo, don Ángel Valbuena Prat, no ocultaba su debilidad por este título cuando reconocía que en él se encontraba la más acertada dimensión de Tirso como historiador, añadiendo que la entonada versificación de La prudencia en la mujer, acomodada a la digna nobleza del cuadro histórico reconstruido, del que pueden servir de ejemplo las octavas iniciales y el romance de la aparición inmediata de doña María, suponen un triunfo decoroso y sobrio en esta intuición de la verdad de las Crónicas, en su caso el primer acierto del teatro nacional (Valbuena Prat Ángel, 1982: 559).

A nosotros lo que nos interesa en nuestro trabajo éste, son las cualidades de la heroína Doña María: una mujer competente para ser jefa, es decir, para ejercer el poder. Además, en esta obra, la heroína da muestras de ginecocracia, entendida en todos sus sentidos: no sólo ha ejercido el poder con valiosos resultados políticos, sociales y económicos, sino también ha superado a los varones (los infantes) en los arcanos de la política, evitando sus trampas, malicias y traiciones, lo que evidencia su supremacía. Pero ¿cuáles son las bazas que posibilitan tales aciertos?: la fe cristiana como identidad espiritual, la prudencia en términos de sabiduría, la buena gobernación, la justicia, la ética, la constancia, la fidelidad, la tolerancia, el respeto de la autoridad, la dignidad, al contrario de la falocracia caracterizada aquí por la política maquiavelista, el asesinato, la calumnia, la mentira, la demagogia, la corrupción, la injusticia y los abusos. Pues, Doña María es verdaderamente empoderada y ginecócrata, lo que hace obviamente de Tirso de Molina, un autor feminista.

\section{Estudio comparativo de las manifestaciones del feminismo y de la ginecocracia en las dos obras}

Los criterios de la comparación son las similitudes y las desemejanzas. La contextualización se hará tomando en cuenta el contexto socio cultural y político moderno en general, y el africano y beninés en particular.

\subsection{Similitudes}

Tal como lo dimos por entendido arriba en la aclaración conceptual y en nuestros breves comentarios sobre las dos obras, las Novelas ejemplares y amorosas y La prudencia en la mujer tratan de temáticas vinculadas con la gente femenina.

Además de esta primera similitud, las dos obras aluden a características psicológicas de las mujeres: María de Zayas habla de credulidad, lo que nosotros preferimos calificar de ingenuidad o candidez, todo lo cual constituye cualidades, en vez de credulidad 
que nos parece peyorativo, porque remite a inmadurez. Esa credulidad o ingenuidad o candidez caracteriza a todos los personajes femeninos de las Novelas ejemplares y amorosas, las traicionadas o abusadas inclusive. A este mismo respecto, Tirso habla de mansuetud o de suavidad. Esta característica se nota sobre todo en la Reina María para con su niño-rey y sus cuñados. Y no por eso, son ellas inmaduras. El mayor rasgo que predispone la gente femenina de las dos obras a la credulidad es la dulzura o mansuetud.

Otra semejanza la representa el buen aseo o la coquetería. En las Novelas ejemplares y amorosas, las mujeres se hacen hermosas y deseables, hasta provocar apetitos sexuales en los varones. A tal coquetería las convida y las alienta la heroína de la obra. En La prudencia en la mujer, la Reina María mantiene una coquetería relevante que constituye una de sus principales bazas que destabilizan a sus celosos cuñados.

Una cuarta similitud: en las dos obras, las mujeres padecen de discriminación sexual por parte de los varones. En efecto, en las Novelas ejemplares y amorosas, las mujeres son menospreciadas y cosificadas por los hombres. Así, en esta obra, muchos hombres las han utilizado como objetos sexuales, y otros las consideran personas para mantener la casa, cocinar, hacer y cuidar a niños, y servir a los esposos. En La prudencia en la mujer, los príncipes y cuñados de la Reina María la consideran incapaz de gobernar e indigna de llevar luto de su esposo, el Rey Alfonso, para con el cual, la sospechan infiel a su memoria.

Total, como similitudes, podemos mentar la credulidad o ingenuidad, la mansuetud o suavidad o dulzura, la coquetería, discriminación sexual y los padecimientos (menosprecio y cosificación). Hace falta observar que las tres primeras similitudes que en realidad son expresiones de características psicológicas, remiten a la feminidad, atributos psíquicos que, -al mismo tiempo que ponen de realce a las mujeres que por su feminidad llegan a ser envidiables o codiciables-, las hacen vulnerables. Si en las Novelas ejemplares y amorosas, las mujeres son víctimas de esta vulnerabilidad, por lo que la heroína condena a los predadores varones y predica que ellas instruyan cursando estudios, leyendo y escribiendo para emanciparse, en La prudencia en la mujer, la Reina María, a sabiendas de que ella está en postura vulnerable, se arma psíquica e intelectualmente para no ser víctima de la vulnerabilidad de su postura de mujer en una sociedad patriarcal. Así que podemos sumar los puntos de similitud a seis: ingenuidad, coquetería, mansuetud, vulnerabilidad, discriminación sexual y padecimientos.

Los dos autores, tratando de temáticas relacionadas con la gente femenina y con miras a defender los intereses morales y sociales de las mujeres, se hacen feministas en la realidad, aunque el concepto de feminismo venía corriendo vigencia desde el Siglo XIX, época tardía para con la creación de sus obras. En cuanto a la ginecocracia, si sus manifestaciones son tangibles en La prudencia en la mujer a través del buen gobierno de la heroína la Reina María, se la deduce en las Novelas ejemplares y amorosas, tomando en cuenta las predicaciones y exhortaciones de Lisis, la heroína más notable en cuanto a la defensa de los intereses de las mujeres.

\subsection{Discrepancias}

Las Novelas amorosas y ejemplares y La prudencia en la mujer se diferencian en unos puntos.

Mientras que en las Novelas ejemplares y amorosas, el feminismo se manifiesta por las predicaciones y otras exhortaciones de Lisis dirigidas a las mujeres para que tomen conciencia de su condición de personas desfavorecidas y menospreciadas en la sociedad, las condenas abiertas dirigidas a los hombres y las culpas que ella las echa tocante a las miserias de la gente femenina, en La prudencia en la mujer, el feminismo y la ginecocracia se manifiestan concretamente por el empoderamiento y el buen gobierno de la Reina Doña María quien, en vez de hablar o de reclamar oralmente cualquier derecho de las mujeres, como lo hace Lisis, ella muestra con maestría su feminismo y su ginecocracia, a través de la intuición femenina, la eficiencia de su gestión juiciosa y de la gobernación en los campos político, económico y socio culturales. También da ella pruebas de un alto sentido de ética, de modestia y de tolerancia en su gobierno político. Pruebas de ello, cuando los príncipes -don Enrique, don Juan y don Diegoquerían oponer el Niño-Rey Fernando IV a su madre Doña María, difamándola en su gestión económica del reino, delante del nuevo rey, ella les ha confundido, demostrando con pruebas concretas y humildad, su propia inocencia y todas las malversaciones de las que fueron culpables los príncipes. A pesar de todo eso, pidió a su hijo-rey que no les castigara, dando así un ejemplo de tolerancia, amor por el pueblo, modestia, buena aura, capacidad de comunicar y compromiso.

\section{Contextualización y actualización de la problemática}

Nuestro estudio contextualizado y actualizado sobre las manifestaciones del feminismo y de la ginecocracia se hará aquí, tomando en cuenta los efectos de las luchas feministas en términos de mujeres que acceden a instancias nacionales e internacionales de gestión política. Además de este parámetro, la contextualización tomará también en cuenta la época (la actualidad: 1990-2021) y las áreas geográficas (el Occidente, África y nuestro propio país Benín). 
En la actualidad, el feminismo propiamente hablando, se defiende a través de ideologías y eslóganes internacionales pro feministas tales como el empoderamiento de la mujer (Women empowerment), el género (gender, approche genre), paridad o igualdad entre hombres y mujeres (Egalité entre hommes et femmes), la discriminación positiva (la discrimination positive), etc.

El empoderamiento de la mujer enfoca el derecho y la obligación de conceder poderes, autoridades, cargos políticos y capacidades económicas a las mujeres a todos los niveles de la vida social, económica y política de cada país. El género lucha para que en todos los proyectos de desarrollo, se tomen en cuenta los intereses de las mujeres. La paridad o igualdad entre hombres y mujeres significa que, en el campo de los derechos, la mujer debe tener los mismos derechos que el hombre. La discriminación positiva especula que, en el goce de derechos laborales y cargos políticos, se conceda la prioridad a la mujer en detrimento del hombre.

\subsection{Mujeres presidentes de repúblicas o jefas de gobiernos}

La mayoría de los países nunca ha sido gobernada por una mujer. Actualmente hay once (según censo de 2018) jefas de gobierno en el mundo, aunque si incluimos jefas de Estado la cifra asciende a veintiuno.

\section{Mujeres jefas de gobierno (2018)}
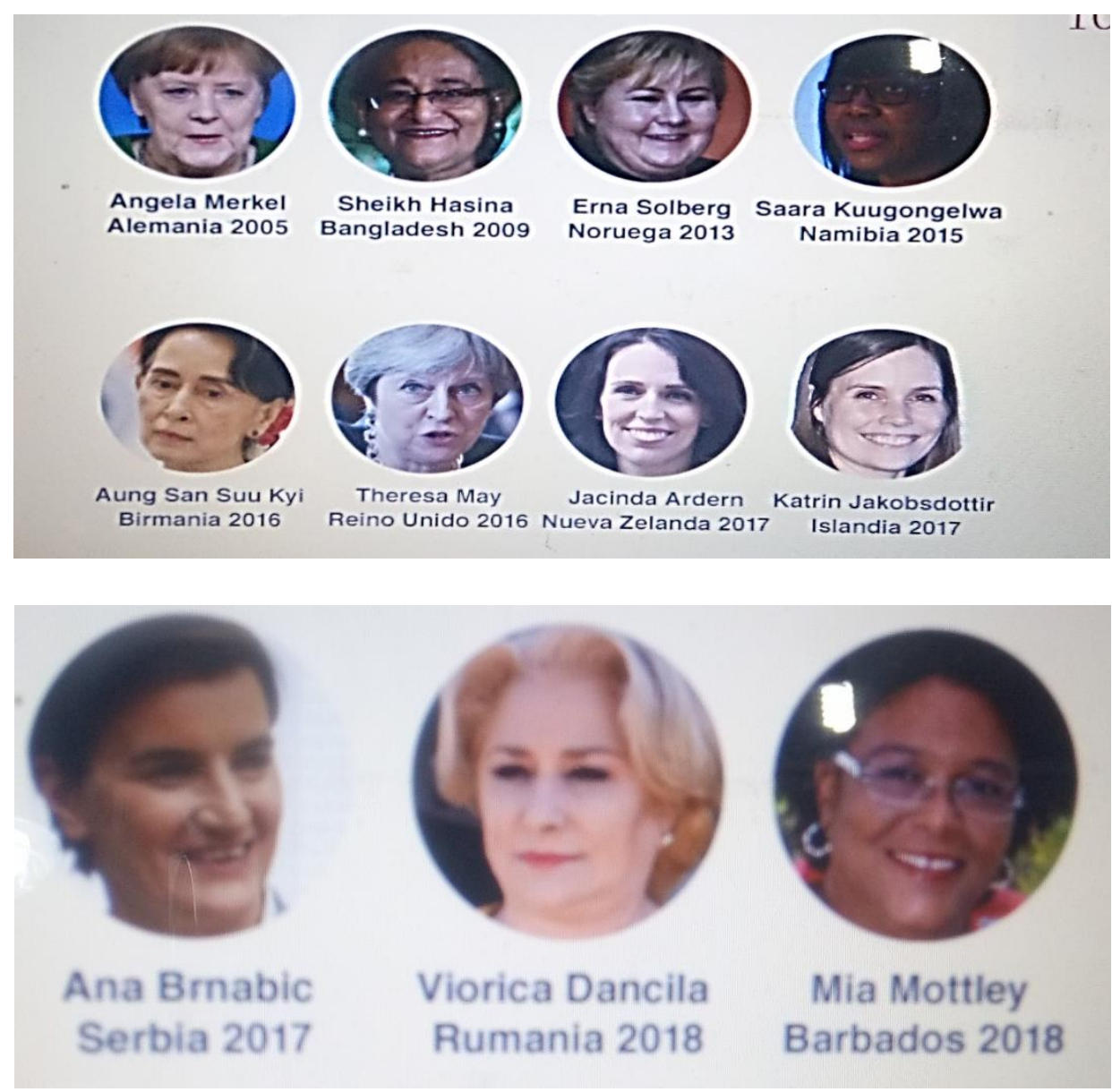

Fuente: (https://www.bbc.com/mundo/noticias-internacionales-53826365) 
Michelle Bachelet, presidente de Chile

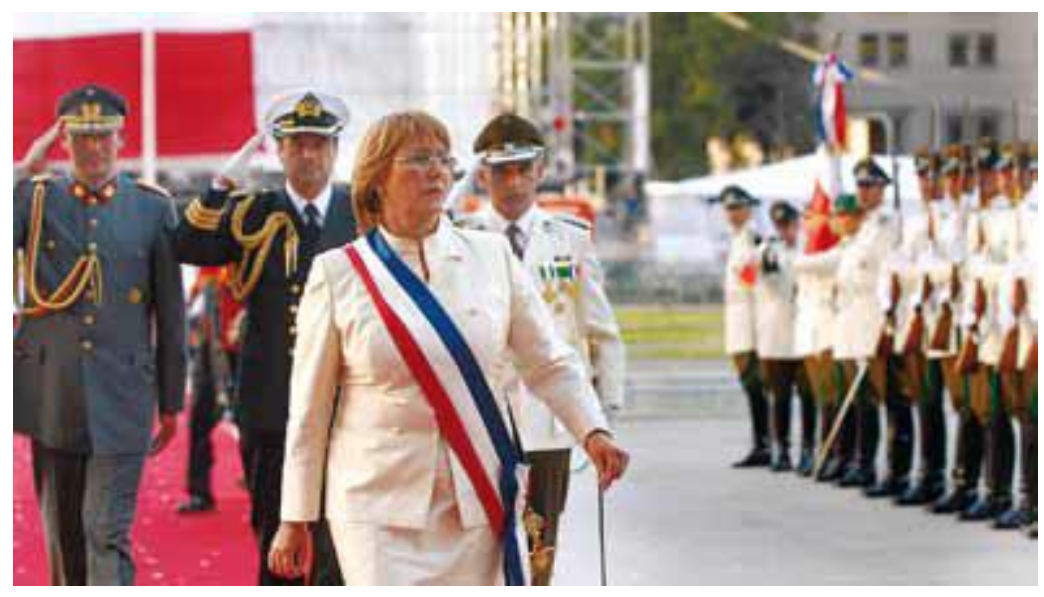

Fuente: Bárbara S. y Gerbert E., Mujeres al poder, 2009: pág. 29

\section{Cristina Fernández, presidente de Argentina}

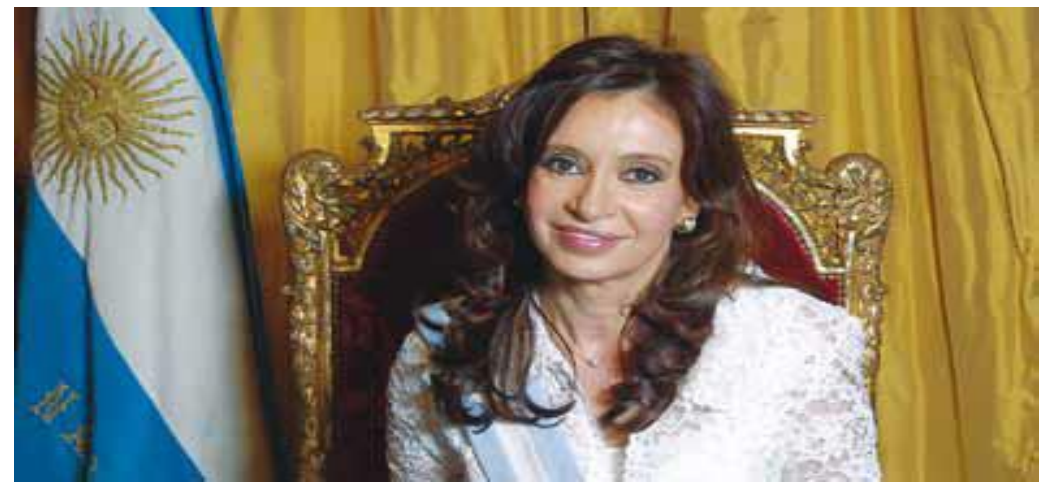

Fuente: Bárbara S. y Gerbert E., Mujeres al poder, 2009: pág. 36

De acuerdo con el Centro de Investigación Pew, en 2017, cincuenta y seis (56) de las ciento cuarenta y seis (146) naciones estudiadas por el Foro Económico Mundial tuvieron una jefa de gobierno o Estado por lo menos un año en la última mitad de siglo. En treinta y uno (31) de estos casos, las mujeres se mantuvieron en el cargo por cinco años o menos, en diez (10) países por sólo un (1) año. Angela Merkel es actualmente la jefa de gobierno que más tiempo ha estado en el cargo. La líder alemana dirige las riendas del país desde 2005. Además de Sheikh Hasina Wazed, quien ahora está cumpliendo su tercer mandato en Bangladesh, las otras mujeres jefas de gobierno han estado en su puesto por cinco años o menos.

\subsection{Mujeres con cargos legislativos y ministeriales}

Un número récord de mujeres están postulándose a elecciones en países de todo el mundo, generando un cambio en el mapa político y haciendo que la igualdad de género en las legislaturas nacionales esté un paso más cerca. México ha elegido el mismo número de parlamentarios hombres y mujeres en ambas cámaras del Parlamento, algo que se considera un hito en el país. El gobierno español, elegido en junio, es el primero desde el regreso de democracia a ese país que tiene más mujeres que hombres en su gabinete.

Por lo pronto, en Estados Unidos, un año después de la derrota de Hillary Clinton en la batalla por la Casa Blanca, hay más mujeres que compiten por puestos en el gobierno que nunca antes. Según datos del Centro para las Mujeres Estadounidenses y la Política, cerca de 470 mujeres —en su mayoría demócratas - se han postulado como candidatas para la Cámara de Representantes en comparación con 298 en 2012 (el número anterior más alto en los registros). Pero si tomamos en cuenta que las mujeres actualmente representan solo el $20 \%$ de los miembros en la cámara de representantes de EE.UU., todavía hay mucho camino por recorrer para dar en el hito. ¿Y qué es de Europa? 
Las mujeres representan más del 30\% en las legislaturas en diecisiete (17) Estados europeas (incluido Mónaco).

\section{Cuadro estadístico de las mujeres europeas en las legislaturas}

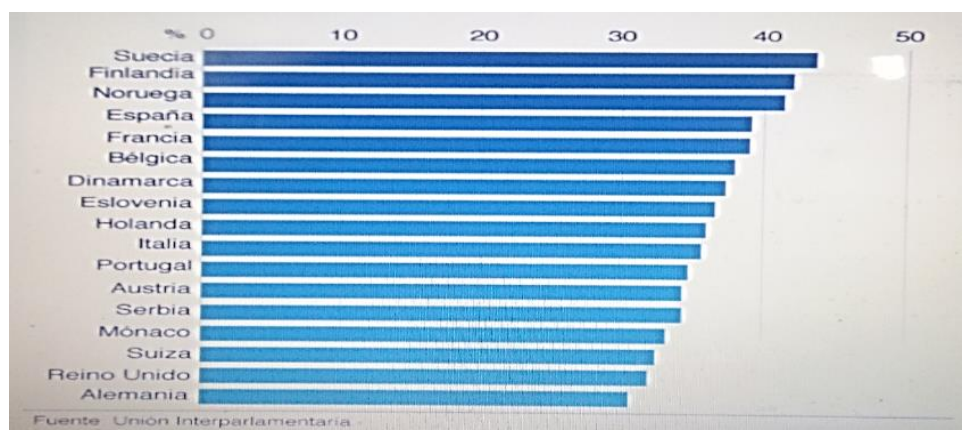

Fuente: Unión Interparlamentaria

España: José Rodríguez Zapatero y las españolas legislativas

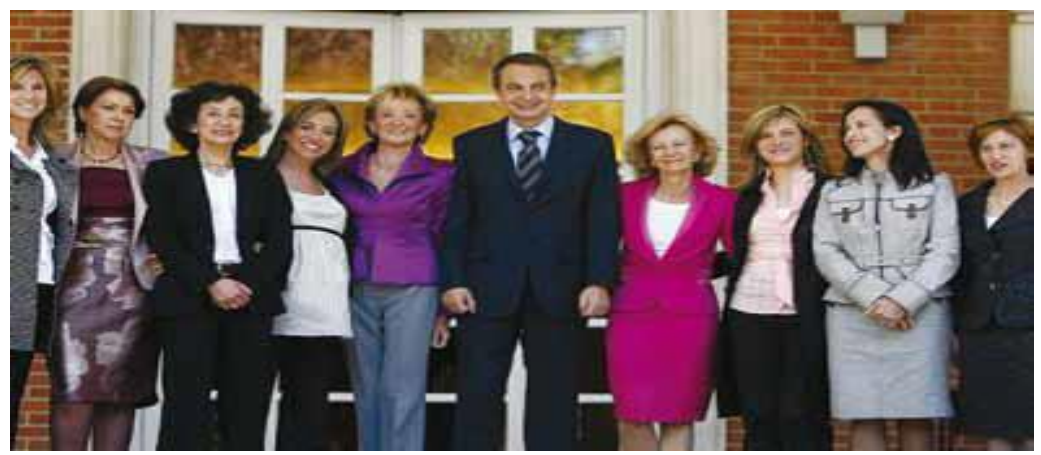

Fuente: Bárbara S. y Gerbert E. 2009: 41

En 2017, un número récord de mujeres se presentó a elecciones en países de todo el mundo, pero no se produjeron grandes cambios. Europa obtuvo la mayor ganancia en cuanto al aumento de mujeres parlamentarias, pero también registró grandes pérdidas. Francia eligió un número récord de mujeres parlamentarias en junio de 2017, con 223 mujeres en las 577 posiciones de la Asamblea Nacional.

En España, el Primer Ministro Pedro Sánchez eligió en junio de 201811 mujeres para formar parte de su gabinete de 17 integrantes.

El Primer Ministro español Pedro Sánchez con su gobierno de acercamiento feminista

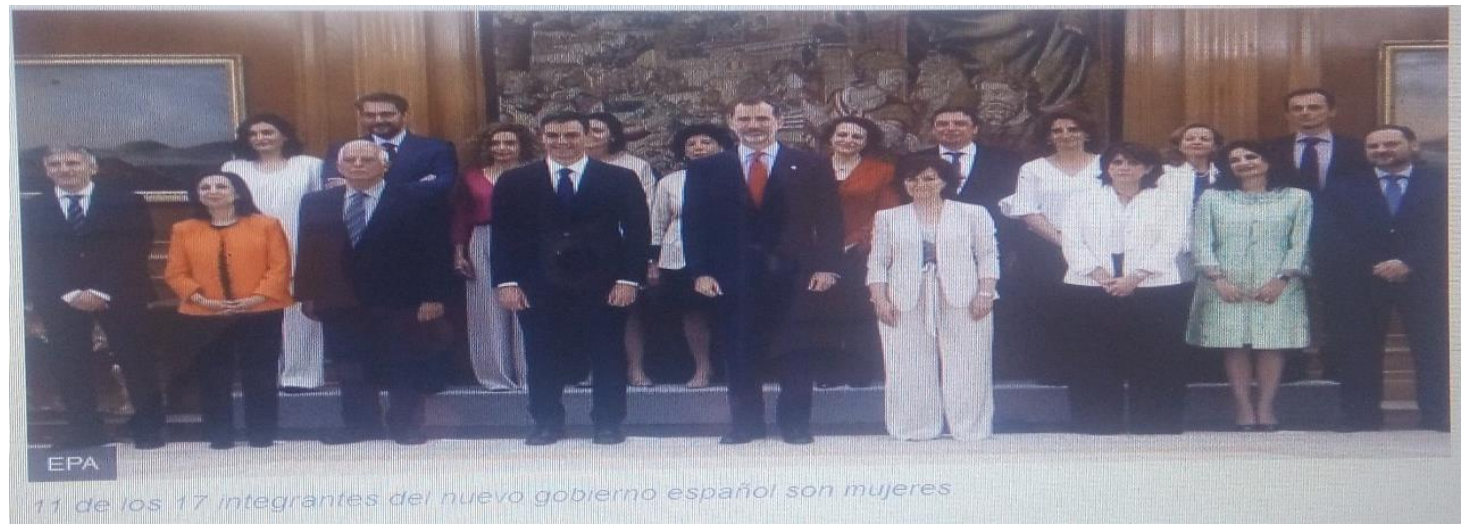

Fuente: Trowsdale, A. (2018): «Los países del mundo donde más mujeres están al poder», in BBC/ Mundo 2020, recuperado de https://www.bbc.com/mundo/noticias-44406170 
Casi todos los países del mundo han registrado un incremento en el número de mujeres parlamentarias desde 1997, cuando la Unión Interparlamentaria (IPU, por sus siglas en inglés) empezó a llevar registro. Hace dos décadas, solo Suecia, Noruega, Finlandia, Dinamarca y Holanda tenían más de $30 \%$ de mujeres parlamentarias, con Suecia encabezando la lista (40,4\%).

\section{Presencia femenina en los Congresos de la región latinoamericana (\%)}

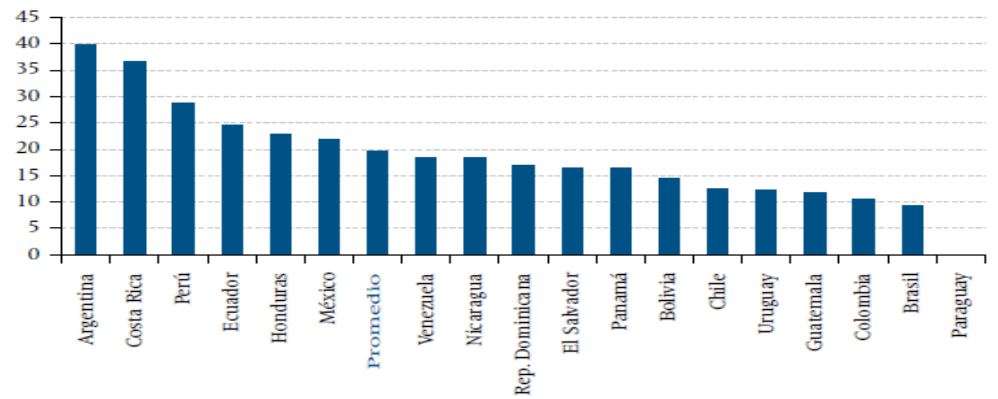

\section{Fuente: Unión Parlamentaria y FLACSO, 2009}

Veintiún (21) años más tarde, hay más diversidad en los primeros puestos de la lista: los países nórdicos fueron superados por Ruanda y varios países sudamericanos y centroamericanos. Bolivia, Granada, México, Nicaragua, Costa Rica y Cuba también están dentro de los primeros diez, todos con más de un $40 \%$ de parlamentarias mujeres. Pero Zeina Hilal, que está a cargo del programa sobre género de la IPU, dice que el progreso hacia la representación igualitaria de hombres y mujeres parece haberse estancado en los últimos años. «Estamos desilusionados y un poco sorprendidas porque hace unos años la tasa del progreso era de un $0,6 \%$. En 2016 y 2017, fue de un 0,1\%. Eso es muy preocupante».

\section{Mapa de las mujeres en legislaturas nacionales (2018 y en \%)}

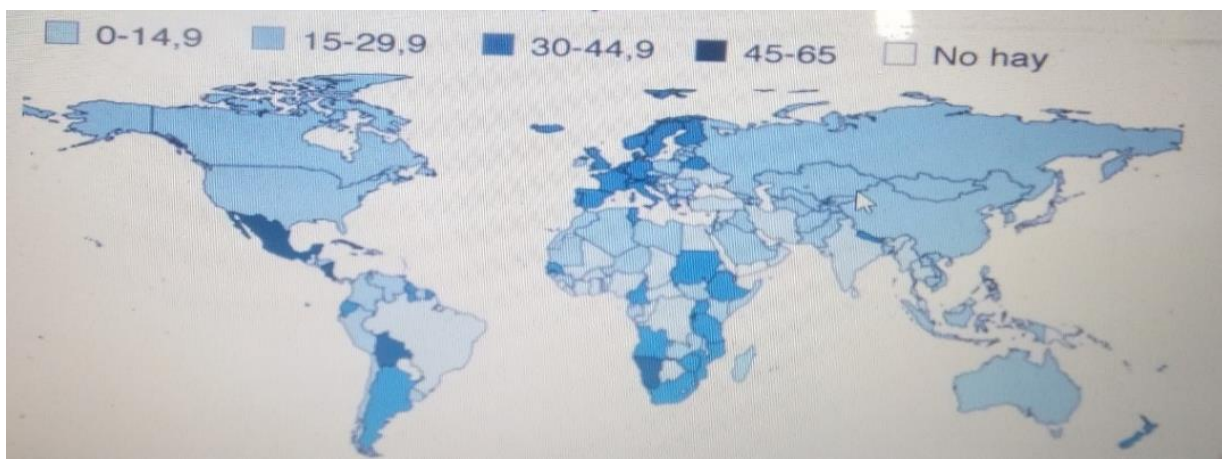

Fuente: Unión Interparlamentaria

Si los índices actuales continúan, el IPU estima que tomará al menos 250 años alcanzar la paridad de género en los parlamentos.

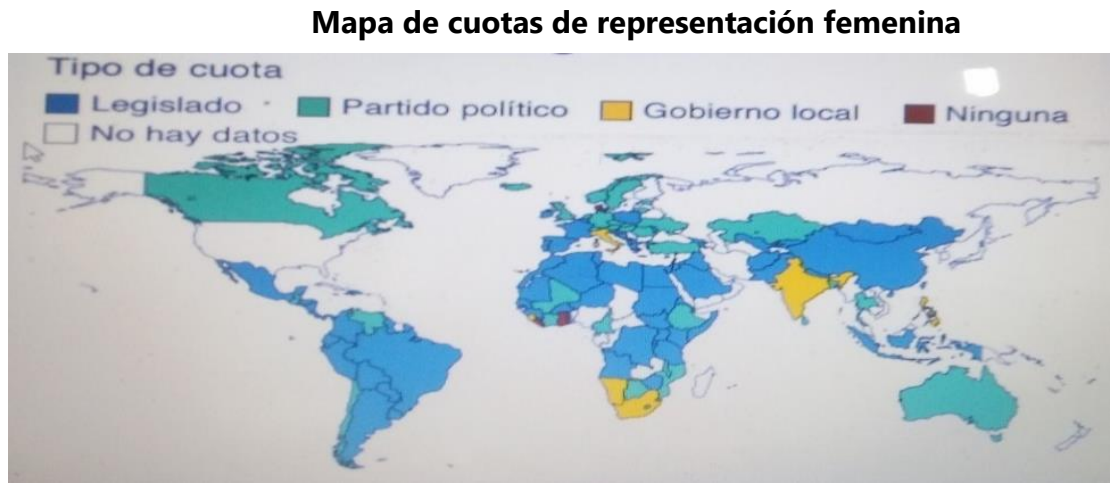

Fuente: Unión Interparlamentaria y FLACSO, 2009. 
Muchos de los países que han visto los mayores aumentos en la representación femenina en el Parlamento introdujeron cuotas por género. Argentina fue el primer país en pasar una ley estableciendo un mínimo de mujeres en 1991.

Investigaciones del IPU muestran que las mujeres obtuvieron el 30\% de las bancadas en los 20 países donde se aplicaron cuotas en 2017 , mientras que solo el $15,4 \%$ de los escaños fueron ganados por mujeres en los 16 países donde no se fijaron objetivos.

Susan Franceschet, directora de Ciencias Políticas de la Universidad de Calgary, en Canadá, cree que hay "décadas y décadas de evidencia de que a menos que tengan que hacerlo, los partidos no eligen candidatas mujeres o no la cantidad de mujeres que nos gustaría". Hay dos tipos principales de cuotas: legisladas, donde un país penaliza por ley si no eligen como candidatas a cierto número de mujeres, y cuotas voluntarias por partido. Estas tienen, según Franceschet, un "efecto contagio", por el que si un partido lo hace los otros se sienten obligados a hacer lo mismo para no parecer que están atrasados en este sentido. La académica señala que hay pocos ejemplos de países donde las cuotas no han servido para hacer una diferencia.

IPU señala solo tres países donde más del $50 \%$ de los escaños en la cámara baja del Parlamento están ocupados por mujeres: Ruanda, Cuba y Bolivia. México está por debajo por poca diferencia, con un 48,6\% de representación femenina.

Ruanda lidera el camino con la proporción más alta de mujeres en la legislatura que ningún otro país. Un cambio en la Constitución en 2003 reservó el 30\% de los puestos para las mujeres. Desde entonces, hay cada vez más mujeres en las elecciones. El cambio en la ley tuvo lugar tras el genocidio de 1994, en el que fueron asesinadas 800.000 personas, en su mayoría hombres. En un esfuerzo por reconstruir el país, las mujeres se vieron obligadas a asumir nuevos roles.

Sin embargo, hay países con menos. Entre los países con los peores récords están Yemen, Omán, Haití, Kuwait, Líbano y Tailandia, con $5 \%$ o menos mujeres parlamentarias.

Por otra parte, hay un número de islas muy pequeñas que no tienen mujeres en el Parlamento, incluidas Vanuatu, Micronesia y Papúa Nueva Guinea, y países como El Salvador y Sierra Leona acerca de los cuales no pudimos encontrar datos sobre cuántas mujeres hay.

Franceschet considera que la paridad de género es una ambición realista e importante, aunque algunas naciones estén muy lejos de lograrlo. "Espero que las mujeres en los países donde el aumento ha sido lento puedan continuar presionando a los partidos y a los líderes políticos para que abran más espacios para candidatas mujeres. Pero no creo que esto ocurra sin la presión continua de las organizaciones de mujeres".

\subsection{El feminismo y el empoderamiento o ginecocracia en Benín}

A nivel nacional, las ideologías feministas internacionales han generado movimientos y organizaciones que se encargan de la educación y de la sensibilización de mujeres en la sociedad. En nuestro país, la República de Benín, actúa una organización feminista llamada RIFONGA (Réseau pour l'Intégration des Femmes des Organisations Non Gouvernementales et Associations Africaines: Red para la Integración de las Mujeres de las Organizaciones No gubernamentales y Asociaciones Africanas). Las mujeres aprovechan esas aperturas internacionales para exigir otros derechos. Es el caso de RIFONGA que aprovecha la igualdad de derechos entre las mujeres y los hombres para lanzar un eslogan arengador: la paridad. Por medio de este eslogan, al inicio, chantajeaban los gobiernos para que se reservasen la mitad de los cargos políticos a las mujeres y la otra a los hombres, sin preocuparse del criterio de competencias. Aquello acarreaba peleas políticas que a veces daban pie a motines que terminaban por represiones policiacas y pérdidas en vidas humanas.

En la actualidad, el feminismo y el empoderamiento se manifiestan tanto a nivel económico como político.

Después de darse cuenta de la extrema pobreza de las mujeres a pesar de su importante contribución en el PIB nacional, el Estado y las ONG actúan juntos para conferir a las mujeres una relativa y apreciable autonomía financiera. El gobierno crea instituciones de micro finanzas que prestan dinero a las mujeres para que emprendan actividades lucrativas tales como pequeños comercios, mini empresas de transformación de productos tropicales o de cultivo de productos de renta tales como el algodón, el acajú, el karité, el soya, etc.

Las ONG, al unísono con algunas instituciones internacionales, capacitan a las mujeres en la gestión de empresas, el cultivo científico de los productos, la transformación de sus productos agrícolas y la gestión financiera. La Iglesia también se compromete en esa lucha, tanto como algunos ayuntamientos de los países del Norte. Por ejemplo, el Ayuntamiento de Burgos en España 
financió a agrupamientos de mujeres en Alada en el Sur de Benín, para la transformación y comercialización de tubérculos y nueces (mandioca y palma). Las Hermanas religiosas salesianas de Don Bosco crean en la capital Cotonú, escuelas y centros de formación técnica de las muchachas para capacitarlas con motivo de independizarlas económicamente. En el Norte, la Sociedad de Misiones Africanas, la Fundación Salvador Soler y los municipios locales, inician proyectos de desarrollo sostenible en los que se organizan las mujeres en asociaciones femeninas que crean huertos que dan el poder a las mujeres, proyectos de huertas que dotan a grupos de mujeres de los mecanismos para su autonomía y empoderamiento, como lo ilustran las imágenes que vienen a continuación:

Imágenes de huertos que dan poder a las mujeres en Benín
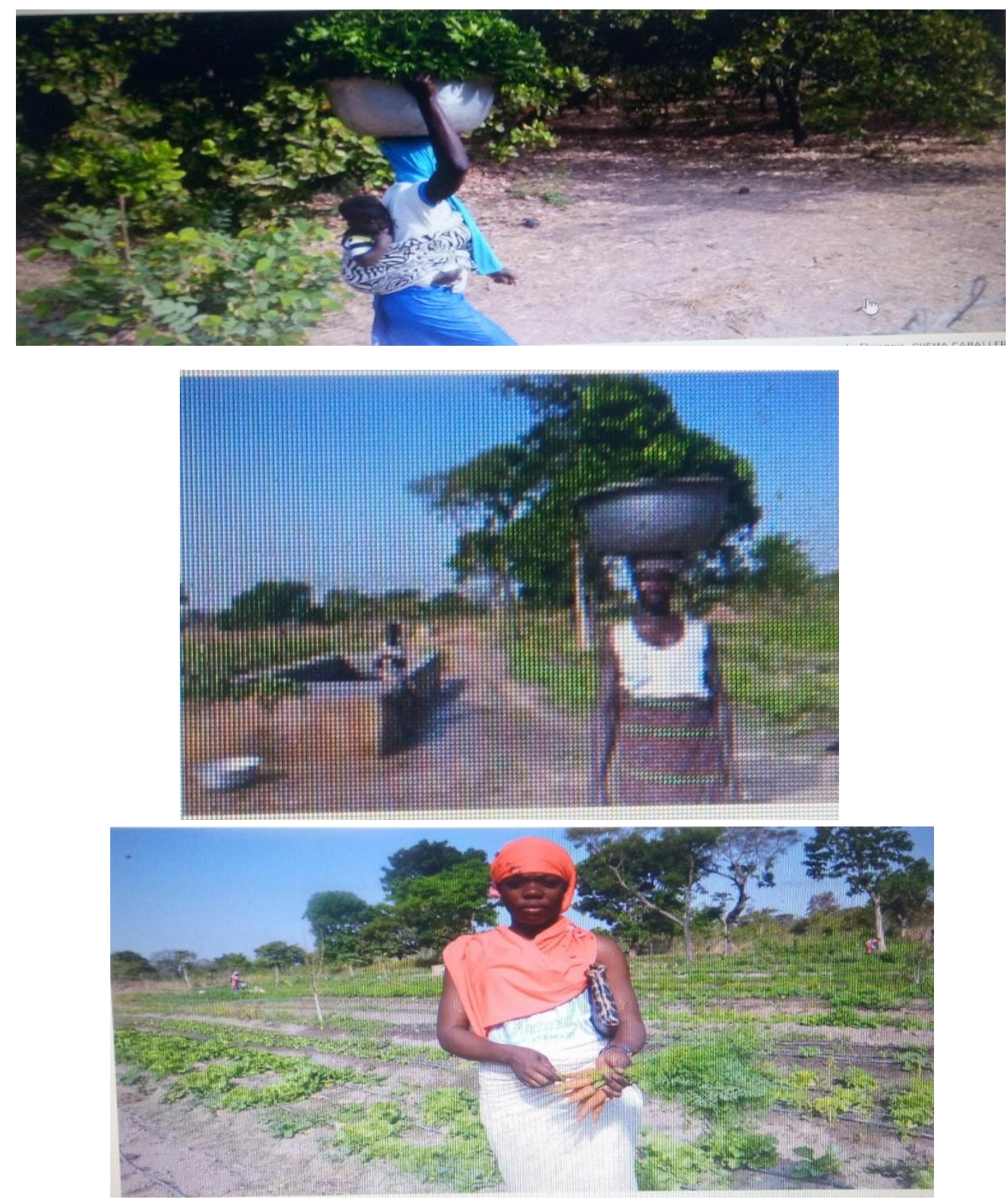

\section{Fuente:https://elpais.com/elpais/2019/07/01/album/1561979253_348691.html}

En dichas Asociaciones, las mujeres muestran con orgullo todo lo que tienen y son muy estrictas con las normas que se han impuesto. Así, las que no cuidan de sus huertas son expulsadas de la Asociación y su terreno es cedido a otra.

En el campo político, las cosas vienen cambiando poquito a poco, hasta que tenemos hoy a una Vice-Presidenta de la República en nombre de Mariam Chabi Talata, al lado del presidente de I a República Patrice Talon 
Presidente de la República Patrice Talon.

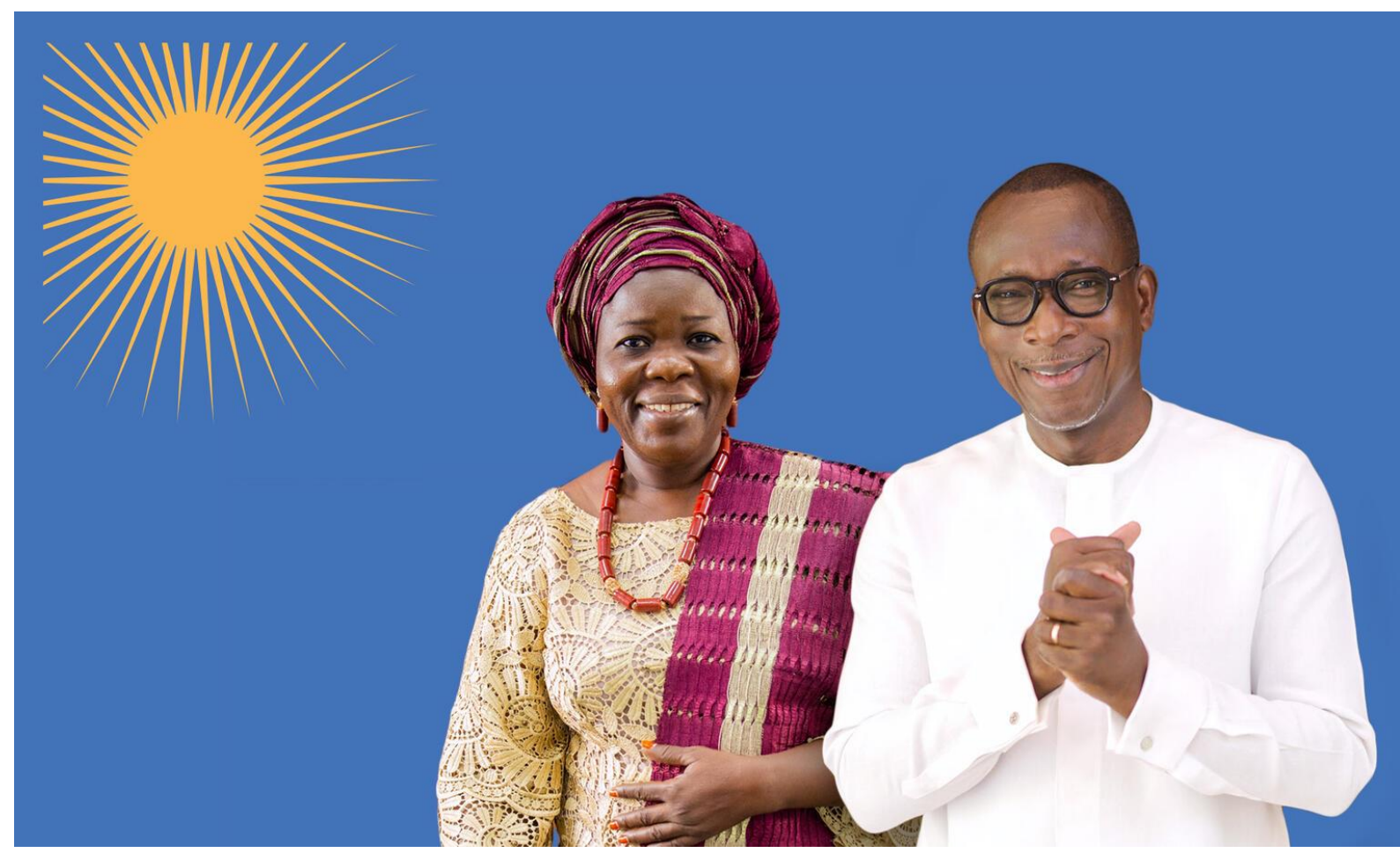

Fuente: La Nation Benin

Aunque se empieza notando los efectos alentadores de las luchas feministas, mucho queda por hacer antes de alcanzar la paridad hombre-mujer que es lo que los actores de esa lucha enfocan realizar.

\section{Estorbos a la emancipación de la mujer y enfoques de solución}

\subsection{Estorbos}

A nivel general, los estorbos remiten a los residuos de la mentalidad falócrata de organizar las sociedades. A este respecto, hasta el vigésimo primer siglo, muchas comunidades sociales siguen viendo atropelladas sus conciencias colectivas por la jefatura femenina, debido a consideraciones socio culturales y religiosas. En menor medida, el mal entendimiento de algunas mujeres que, a través de sus comportamientos, dejan pensar que su feminidad y su activismo a veces violento y agresivo, bastan para ocupar cargos políticos, en vez de manifestar verdaderas pruebas de competencias.

\subsection{Enfoques de solución}

La primera solución que proponemos es la legislación pro feminista. Hace falta seguir creando leyes con motivo de suprimir la discriminación sexual, en reconocimiento de las competencias de las mujeres. Después de crear esas leyes pro feministas, hace falta crear también mecanismos de seguimiento de su aplicación. Todo lo que requiere una legítima voluntad política por parte de los Estados.

Además de esa solución legislativa y política, los criterios de promoción socio política y económica deberán ser objetivos y conformes con el mérito técnico y gerencial, en vez del único activismo político. La Reina doña María en La prudencia en la mujer de Tirso de Molina, nos da un ejemplo ilustrativo de tales competencias técnicas y gerenciales.

Por fin, las mismas mujeres deberán organizarse para que el liderazgo socio político femenino corra pareja con los atributos tradicionales de la gente femenina: la vida en pareja y la maternidad. El feminismo en general gozará de plenitud, y la ginecocracia en particular se hará realidad provechosa, cuando la jefatura femenina se encarne o se manifieste por mujeres líderes que viven en parejas formales y son madres de familias.

\section{Conclusión}

En resumidas cuentas, María de Zayas Sotomayor y Tirso de Molina, a través de sus obras Novelas amorosas y ejemplares y La prudencia en la mujer, tratan de feminismo y de empoderamiento de la mujer, con algunos rasgos diferenciales. Si en las Novelas 
amorosas y ejemplares el feminismo se manifiesta por las predicaciones y otras exhortaciones dirigidas a las mujeres para que tomen conciencia de su condición de personas desfavorecidas y menospreciadas en la sociedad, las condenas abiertas dirigidas a los hombres tocante a las miserias de la gente femenina, en La prudencia en la mujer, el feminismo y la ginecocracia se manifiestan concretamente por el empoderamiento y el buen gobierno, por la intuición femenina, la eficiencia gerencial en la gobernación política, económica y socio cultural, el sentido ético, la modestia y la tolerancia.

De la contextualización y actualización de la problemática, podemos mentar que el género femenino y el poder vienen corriendo pareja hoy día a nivel universal, hasta en las áreas socio culturales africanas, aunque unos países están más adelantados que otros a este respecto. Así que en la actualidad, se encuentran mujeres a todos los niveles de jefatura. Los frenos actuales al empoderamiento de la mujer son debidos a la insuficiencia de legislación en la materia, y a la reticencia de algunas comunidades patriarcales falócratas que ven en este movimiento, trastornos socio culturales de malos augurios.

Como soluciones a los estorbos al empoderamiento de la mujer, proponemos que, además de la legislación pro feminista y de los criterios de competencias técnicas y gerenciales que deben caracterizar a la gente femenina que empoderar, hace falta que el liderazgo femenino vaya junto con los atributos tradicionales femeninos de miembro de legítima pareja mixta y de madre de familia.

\section{Referencias}

[1] Caballero, C. (2019). «Huertos que dan el poder a las mujeres», in El País S.L. del 5 de julio de 2019

[2] Caballero, C. (2019). «Los motivos por los que los jóvenes de Benín alzan la voz», El País S.L. del 24 de julio de 2019

[3] Chabás J. (1962). Historia de la literatura española, Santiago de Cuba: Artes gráficas.

[4] Fernández, M. A. (2007). Bienvenida Paridad, Santiago de Chile : Editorial Cuarto Propio,

[5] Genovese, M. (1997): Mujeres líderes en política: modelos y prospectiva, España: Nancea,

[6] González, M. y al. (2011): Clave, Diccionario de uso del español actual, Madrid: Ediciones S.M.

[7] Lista A. (1844): Ensayos literarios y críticos, vol. I, Madrid: Ed. Arial

[8] Medenou C. B. (2018): «Problemática de feminidad y gineconomía: estudio histórico literario de los dos fenómenos», in Les Annales de la FLLAC, La Revue de la Faculté des Lettres, Langues, Arts et Communications, Vol. 1, N¹, págs. 155-164

[9] Merlet Ph., Berès A. y al. (2003): Le Petit Larousse Grand Format 2003, París: Larousse/VUEF

[10] Nolasco P. (1949): Estudios, Madrid: Castilla S.A.

[11] Pallares B. (1982): Tirso de Molina, la huerta de Juan Fernández, edición, prólogo y notas, Madrid: Clásico Castalia.

[12] Pallares B. (1984): Tirso de Molina, La villana de la Sagra y El colmenero divino, Madrid: Clásico Castalia.

[13] Palenca González, Á. (1932): La junta de reformación, Madrid: Ed. Artes.

[14] Palenca González, Á. (1945): Quevedo, Tirso y las comedias ante la Junta de Reformación, en Boletín de la Real Academia Española, XXV, Luján, pág. 84

[15] Penedo, M. (1949): Tirso de Molina, Aportaciones biográficas en Estudios, , Madrid: Editorial Artes.

[16] Ríos T. M. (2009): Mujer y política. El impacto de las cuotas de género en América Latina, Santiago de Chile: Ed. FLACSO / IDEA Internacional / Catalonia.

[17] Ríos (de) B. (1946): Obras completa s I, Madrid: Aguilar

[18] Ríos (de) B. (1910): Las mujeres de Tirso en su libro del siglo de oro, Madrid: Aguilar

[19] Ruiza M., Fernández, T. y Tamaro, E. (2004). «Biografia de María de Zayas», in Biografías y Vidas. La enciclopedia biográfica en línea. Barcelona (España). Recuperado de https://www.biografiasyvidas.com/biografia/z/zayas.htm el 5 de mayo de 2021.

[20] Stiegler B. y Gerber E. (2009): Género y poder, Santiago de Chile: Friedrich-Ebert-Stiftung

[21] Torres N. G. (2010): Tirso de Molina, La prudencia en la mujer, Madrid: Cátedra.

[22] Trowsdale, A. (2018): «Los países del mundo donde más mujeres están al poder», in BBC/ Mundo 2020, recuperado de https://www.bbc.com/mundo/noticias-internacionales-53826365 